\title{
Fragmentos manuscritos hebraicos del Arxiu Municipal de Girona sobre enfermedades genitales y sus remedios: edición, traducción y glosario*
}

\author{
Christa Casals Stenzel ${ }^{* *}$ \\ Institut d'Estudis Nahmànides, Girona
}

\begin{abstract}
Estudio de varios fragmentos manuscritos que contienen textos médicos y farmacológicos recuperados de las cubiertas de un Llibre d'àpoques (recibos de los pagos realizados por el clavario en nombre del concejo) del año 1380 del Arxiu Municipal de Girona. Los dos bifolios y el fragmento estudiados tratan de dolencias genitales en mujeres y en varones y de sus remedios y pertenecen al mismo manuscrito y eventualmente a un mismo autor. Los textos se han ordenado siguiendo un criterio temático con objeto de reconstruir la disposición original. El texto está en hebreo y contiene términos técnicos en lengua romance catalana (en cursiva, en la traducción), y permite elaborar un glosario de farmacopea de gran valor lingüístico e histórico, además de aportar información sobre su pronunciación.
\end{abstract}

Palabras Clave: medicina; judaísmo; historia; siglos XIV y XV; farmacopea; Galeno; enfermedades del útero; enfermedades de los genitales masculinos; lengua catalana; manuscritos hebreos; Cataluña.

Hebrew Script Manuscript Fragments from the Municipal Archives of Girona on Genital Diseases and their Remedies: Edition, Translation and Glossary.- Two bifolios and one fragment from among the fragments of medical and pharmacological texts found in the binding of the Llibre d'Apoques (containing the receipts of payments made by the clavario on behalf of the municipal council) dating from 1380 from the Municipal Archives of Girona, are analyzed because of their linguistic and historial value. The writing and the presentation suggest that they share the same author. Relying on content details, the author presents a probable arrangement of the pages' original order. Many of the botanical terms are given in the Catalan language (they appear in the translation in cursive letters). The rendition of the Catalan words in Hebrew letters enables us to know their pronunciation at the time.

* Agradezco a Joan Boadas, director del Arxiu Municipal de Girona por facilitarme los documentos necesarios para llevar a cabo este trabajo y sobre todo a Sílvia Planas, directora del Institut d'Estudis Nahmànides por la gran ayuda y el tiempo que me ha brindado. Extiendo el agradecimiento a los evaluadores anónimos de Sefarad por sus comentarios.

*** christa.casals.wiesner@web.de 
KeYwords: Medicine; Judaism; History, $14^{\text {th }}-15^{\text {th }}$ Centuries; Pharmacopea; Galen; Diseases of the Womb; Diseases of Male's Genitals; Catalan Language; Hebrew manuscripts; Catalonia.

El reciclaje de material manuscrito e impreso en desuso para la encuadernación de libros ha sido una práctica recurrente hasta nuestros días. Los materiales recuperados de las cubiertas de manuscritos han abierto nuevas perspectivas en la investigación de la cultura judía medieval con la incorporación de nuevos textos hasta ahora desconocidos.

Así ocurre con los restos de un manuscrito que contiene varios capítulos sobre el tratamiento de enfermedades genitales de varones y mujeres y que se conserva entre los fragmentos recuperados en los fondos del Arxiu Municipal de Girona. Se trata de los restos de un compendio médico hallado en las cubiertas de un Llibre d'àpoques correspondiente a 1380. La serie documental de libros de ápocas está relacionada con la administración municipal. Las ápocas eran recibos de los pagos y transacciones del clavario en nombre del consejo municipal. La fecha del libro no implica que el manuscrito hebreo fuera anterior a 1380, puesto que la encuadernación se realizó después de esa fecha.

Del material hallado he elegido dos bifolios (núm. 23 y 27) y un fragmento que contiene las últimas cuatro lineas de otro folio (núm. $31 \mathrm{~b} 2 \mathrm{v}$ ), y ello por la coherencia temática que presentan, pues el contenido está relacionado con el tratamiento de enfermedades y problemas genitales de mujeres y hombres.

En el estado actual de la investigación me ha resultado imposible reconstruir el manuscrito en su orden original. Solamente el fragmento $31 \mathrm{~b}$ $2 \mathrm{v}$ nos indica a pie de página el lema del asunto que se trata al comienzo del folio siguiente: לכאב האם 'Contra el dolor de la matriz', y que encontramos en el fol. $23 \mathrm{~b}$ r.

Los textos transcritos corresponden a nueve páginas, de las que únicamente cuatro, las correspondientes al bifolio núm. 23 se conservan íntegramente. El trazado de la escritura es regular, y corresponde a una semicursiva hispano-judía de los siglos XIV y XV. El número de líneas por página, 29, es también regular. Los dos bifolios tienen las siguientes medidas: 290 x $195 \mathrm{~mm}$ (23), y 285 x $180 \mathrm{~mm}$ (27), y el fragmento 31b aparece recortado $(150 \times 50 \mathrm{~mm})$. El orden de los folios que he seguido 
en la transcripción de los fragmentos es el siguiente: 27b r, 27a v, 23a r, $31 \mathrm{~b} 2 \mathrm{v}, 23 \mathrm{~b}$ r, 23a v, 27a r, 27b v y $23 \mathrm{~b}$ v.

Los cinco primeros fragmentos tratan de asuntos ginecológicos, interמכאב הכליות מ 'Sobre el dolor de los riñones'. Los últimos cuatro folios se refieren a dolencias genitales masculinas. Cada tema aparece precedido por un titulo escrito con trazado más grueso.

Otros textos no incluídos en este artículo tratan de problemas oculares, intestinales, cardiacos y de la circulación de la sangre etc., pero no son tan extensos como los elegidos.

Tampoco me ha sido posible identificar dichos fragmentos con ningún otro texto publicado, y no podemos determinar de momento su autoría, ni su título, a partir de la evidencia textual interna de los fragmentos recuperados.

Se trata de una obra de carácter heterogéneo, de medicina empírica que sería usada por un practicante judío. Junto a la descripción de la dolencia, o al final del remedio o del medicamento compuesto, se indica la forma en la que este debía ser administrado. El estudio de la medicina judía medieval ha experimentado un impulso importante en las dos últimas décadas, con la publicación de nuevos textos ${ }^{1}$, y los fragmentos que presento aquí tienen un doble interés, científico médico-farmacológico y lexicográfico.

Ofrezco a continuación una transcripción y una traducción del texto, dejando para el glosario final las anotaciones lexicográficas (relativas tanto a la botánica y mundo animal, como a los términos médicos y pesos y medidas). He aprovechado para señalar en cursiva términos que aparecen en romance en escritura hebraica, además de algún tecnicismo (pesos y medidas, etc.) hebreo. He añadido a la edición del texto hebreo una puntuación moderna para facilitar su lectura. Las referencias bibliográfias completas del glosario aparecen en la lista que le precede.

\footnotetext{
${ }^{1}$ Gerrit Bos, «On Editing and Translating Medieval Hebrew Medical Texts», JQR 89 (1998), 101-122.
} 


\title{
TRADUCCIÓN
}

[27b r $][\ldots .]_{1}$ sarcocola $^{2}[\ldots]_{2}$ otro remedio: Coge cáscara de granadas $[\ldots]_{3}$ y limpia el lugar siempre que [... $]_{4}$ coge una hierba llamada erba ru[bia] [... ${ }_{5}$ y beberá el zumo cada día y estos y $[\ldots]_{6}$ por esto hará de ella un emplasto $[\ldots]$ y $[\ldots]_{7}$ y la fisura causada por un salto. $\mathrm{Y}$ ha de vigilar de beber agua de caldo y de [..]. ${ }_{8} \mathrm{Y}$ es beneficioso para esto un baño de vapor, para las entrañas que salen ${ }^{3}$, llamadas bodel $^{4}[\ldots]$ ${ }_{9}[\ldots]$ el vientre: Coge segell [de Salomó] y hiérvelo en agua [... ${ }_{10}$ [y trata] la dolencia siempre por abajo con un recipiente hecho a propósito. Otro remedio: Coge 10 [...] ${ }_{11}$ y tritura y haz un emplasto [que pondrás] sobre los testículos, o [prepara] una bebida y sanará.

\begin{abstract}
Sobre la menstruación: Cuenta Gale[no] ${ }^{5}$ : [abandonaba] una enfermería [...] ${ }_{13}$ cuando vi a una mujer [...] que se le había interrumpido su menstruación cuatro meses y se había debilitado ${ }_{14}$ mucho y le faltaban las ganas de comer y cuando vi lo que expulsaba, [ordené] una sangría durante 3 días: ${ }_{15}$ en el primer día se le extrajo una litra, en el segundo una litra, y en el tercero una litra [...] y después con una medida ${ }_{16}$ más pequeña, y que volviera a comer su misma dosis. Y también es útil para la fertilidad de las mujeres calement del desierto.
\end{abstract}

[27av $[\ldots . .]_{1}[\ldots]$ calement: $[\ldots]_{2}[\ldots]$ añade 4 dracmas de escamonea ${ }_{3}[\ldots]$ dr[acmas $]$ y media de casia, sabina, ${ }_{4}[\ldots]$ mezcla con jugo de api, y haz ${ }_{5}[\ldots]$ será enjuagado este pesario. ${ }_{6}[\ldots]$ genciana, solidago, mirra y mezcla con hisopo, ireleos ${ }_{7}[\ldots]$ como estos, calement y miel de safco ['saúco']. ${ }_{8}$ [...] estos con aceite de rosas o con aceite de iris a fin de que no se produzcan ${ }_{9}[. .$.$] llagas o tumores ahí. También se le calienta$ de esta forma: aceite de ${ }_{10}[\ldots]$, aceite de sambuc, aceite de melilot, casia, anís, arodnico ['barba de Arón'], irios ['lirios'], calement ${ }_{11}$ [...] y semejantes, bien sean alisados, bien sean prensados o atados y todos juntos cocidos en agua. ${ }_{12}[\ldots]$ mézclense, séquense y caliéntese a la mujer con ello. Y así, si la mujer se sienta sobre todo esto ${ }_{13}[. .$.$] hervido en un puchero, el vapor que penetrará en su interior será bueno para ella.$

${ }_{14}$ Para impedir un embarazo: Coge el diente de un niño que esté a punto de caer, y mételo en una copa de ${ }_{15}$ plata antes de que caiga a tierra y cuélgalo sobre la

\footnotetext{
${ }^{2}$ Goma aromática amarga, usada para curar heridas.

${ }^{3}$ Se refiere a una hernia.

${ }^{4}$ Este término está vocalizado, por eso bodel, en cat. budell 'intestino'.

${ }^{5}$ En Trotula, 67 se cuenta el mismo acontecimiento, pero ahí son nueve meses en los que la mujer no tenía la menstruación, y se especifica de qué parte del cuerpo se ha de extraer la sangre.
} 
TRANSCRIPCIÓN DE LOS FRAGMENTOS

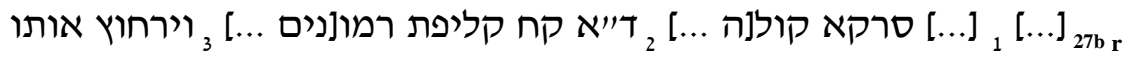

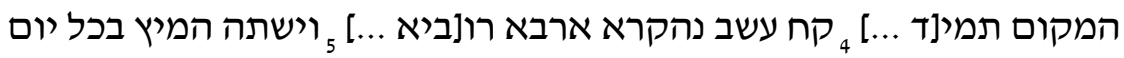
והם והע[...] ${ }_{6}$ לכך יעשה ממנה תחבושת [...] וא[...] משתות מי מרק ומ[...] ועזר לזה אשטובה למעי היוצא שקורין בוֹדָיל [...] , הבטן, קח שגל ותרתיח אותה במים [...] החולי תמיד מתחתיו בכלי העשוי לכך. ד"א קח י" [...] וכות ואשה ת[חבוש]ת על הביצים או לשתות וירפא.

12 מהנדות : אמר גלי[נוס] ו[אפס]יק אפירמריא [...] אשר נפסקו פרחיה ארבעה חדשים ינרזו פני[ה] ${ }^{14}$ מאד והפטירה חפץ המאכל, וכאשר ראיתי את הוצא [...]לה מן הדם ג' ימים: 15 בראשון הוצאנה לה ליטרא ובשני ליט׳ ובשלישי ליט’ [...], ואחר כן בשיעור 16 מועט ושבה בורתה למתכונתה. וגם [יועיל] לפרחי הנשים קלימנט מדבר

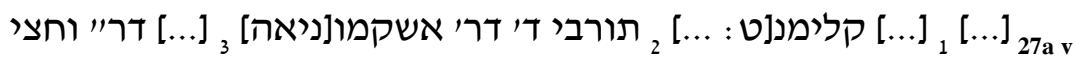

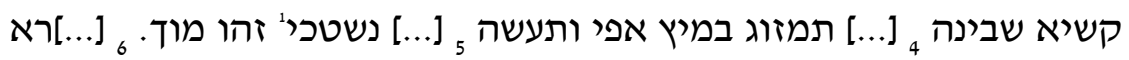
גנסיאנה, אלום, מירא ותמזוך² עם אזב, איריליאוש, [...]א כאלה, קלימנט ודבש די ספקו. [...] הם עם שמן ורד או עם איריליון בעבור שלא יולד, [....

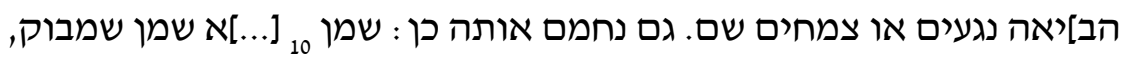
שמן מלילוד, קשיא, אניס, ארונידקו, איריוש, קלימנט, [.... ודו[מיהם או

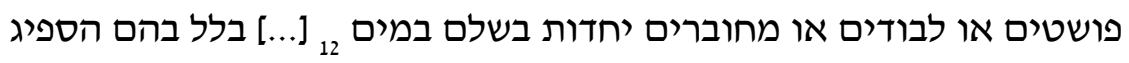
ותחמם האשה בם. וכן אם האשה [תשב] על [כל] אלה 13 ובושלים בתוך הכלי אש העשן יכנס בפניה טוב לה.

$14{ }_{14}$ קודם שתפיל לארץ ותתלה על אשה וימנע מן הריון. אחר 16 [... לנ]תנה רואת ארנבת על האשה וימנע מן ההריון. נינטר ${ }^{1}$ תמזוג 
mujer e impedirá el embarazo. Otro ${ }_{16}$ [remedio]: Póngase excremento de conejo sobre la mujer e impedirá el embarazo.

\section{Para provocar la menstruación}

$[\ldots]$

[23a r] 1 Coge marrubi blanco y cuécelo con vino blanco en una olla nueva y se sahumará a la mujer ${ }_{2}$ con esto durante el tiempo siguiente: 3 días, 3 veces cada día o durante 3 noches, y esto es provechoso ${ }_{3}$ para la concepción.

Un pesario que hace maravillas: Meterá un poco de las hierbas del acoro ${ }_{4}{ }_{4}$ que se encuentra entre las acequias y es como el abrojo ${ }^{7}$, y se limpiará la matriz de todo humor malo y vendrá su menstruación en una noche y se restablecerá.

${ }_{6}$ Para que le venga su menstruación: Coge ada $^{8}$, semilla de ruda, y añade triple cantidad de vino bueno y dáselo a beber ${ }_{7}$ y le vendrá la menstruación.

Un pesario para la mujer a fin de que le venga pronto la menstruación: Coge marrubi ${ }_{8}$ masculino, machácalo bien, y la misma cantidad de leche de oveja, bátela y mézclala con ${ }_{9}$ la hierba y echa todo en un bañera de vapor de cobre, o de otra forma, sumergido en agua, ${ }_{10}$ ponlo debajo de las ascuas hasta que esté cocido, y expulsará en gran cantidad las impurezas que se hayan formado. ${ }_{11} \mathrm{Y}$ mete lana que no [quede] empapada, e introdúcela en el útero y saldrán todas las heces malas ${ }_{12}$ y los gases que causan hinchazón y dolor. [Esto] está comprobado de boca de un sabio.

${ }_{13}$ Otro remedio: Désele de beber zumo de cebolla. Otro [remedio] bien desecativo: Mete ascuas ${ }_{14}$ en una olla grande nueva y pon sobre ella [...] e incienso, y sobre todo su vapor secará su enfriamiento. ${ }_{15}$ Póngase en pie sobre su bastón, como [si tuviera] sus piernas débiles por el reuma, ${ }_{16}$ [cuidando] que no se esfume el vapor. Ha de hacer esto durante 3 días y sanará. Y ayuda a la flor ${ }_{17}^{9}$ aršemiša hervida con harina de cebada; que repose seguidamente; o maja su raíz ${ }_{18}$ y dale de beber su zumo con buen vino blanco. Y está escrito y seleccionado que fácilmente se la limpiará. ${ }_{19} \mathrm{O}$ coja la hierba cocida con jugo de fenigrec, májalo todo junto, unta lana y la calmará.

\footnotetext{
${ }^{6}$ Acorus calamus.

${ }^{7}$ Tribulus silvestris.

${ }^{8}$ La palabra aparece sin la primera vocal.

${ }^{9}$ Menstruación.
} 


\section{להביא נדות}

23ar

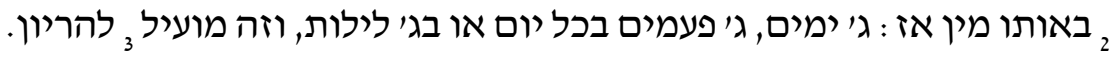

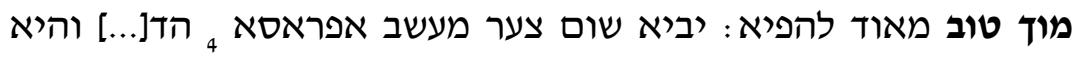

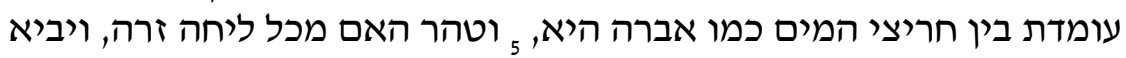
נדותה בלילה אחת ותקבל הרפוי[ה].

6 להביא נדותה: [ק]ח רדא זרי3 רודא ושים שם שליש מין טוב ותשק[ה]

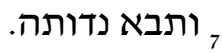

מוך לאשה להביא לה נדות תכף: קח מנרובי] זכר זכר וכוש־ אותו היטב

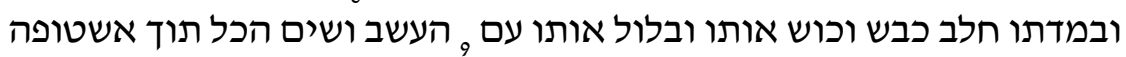

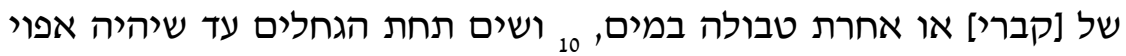

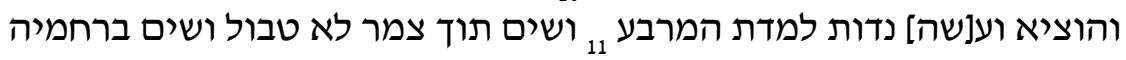

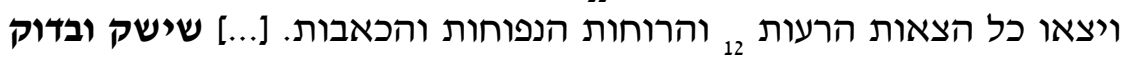

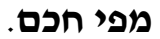

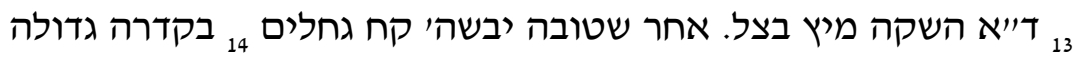

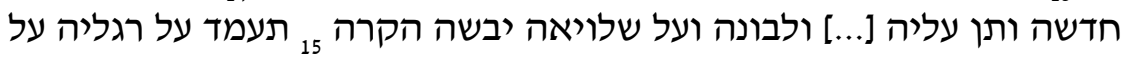

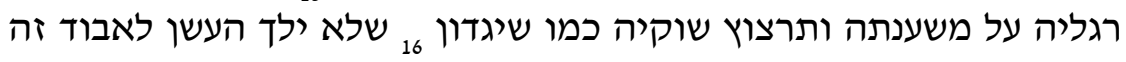
תעשה ג' ימים ותרפא ואודר פר'

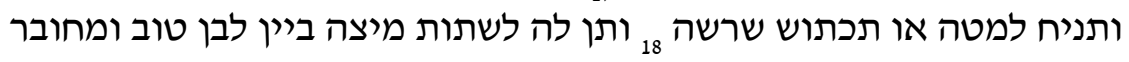

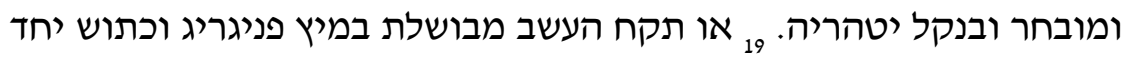

ותטוח צמר ותנוח לה. ומרחיח.

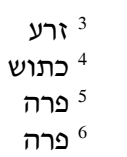




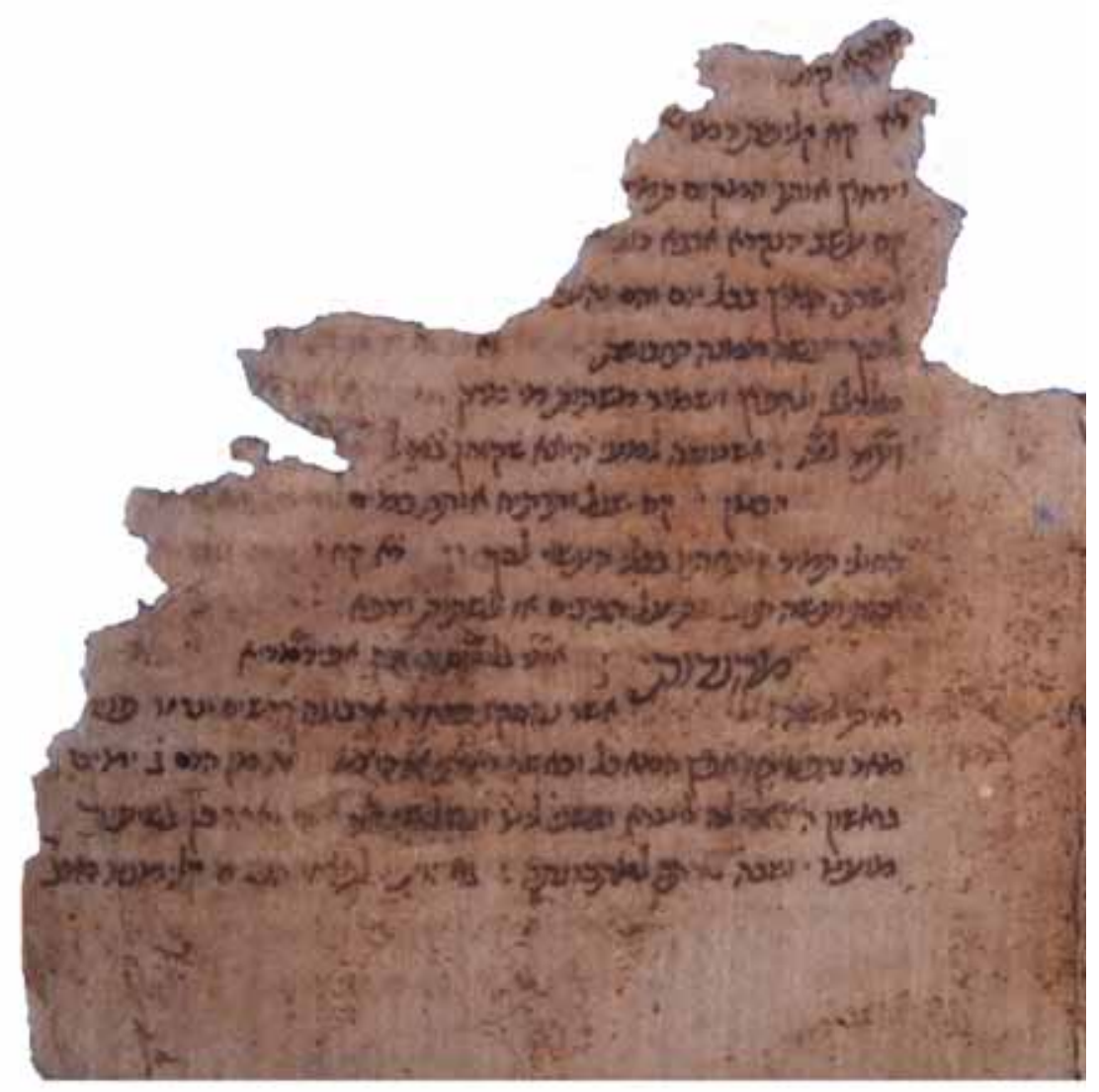

Figura 1. (C) Arxiu Municipal de Girona [= AMGi], Col·lecció de documents hebreus, HB27b r.

SEFARAD, vol. 74:1, enero-junio 2014, págs. 33-74. ISSN: 0037-0894. doi: 10.3989/sefarad.014.002 


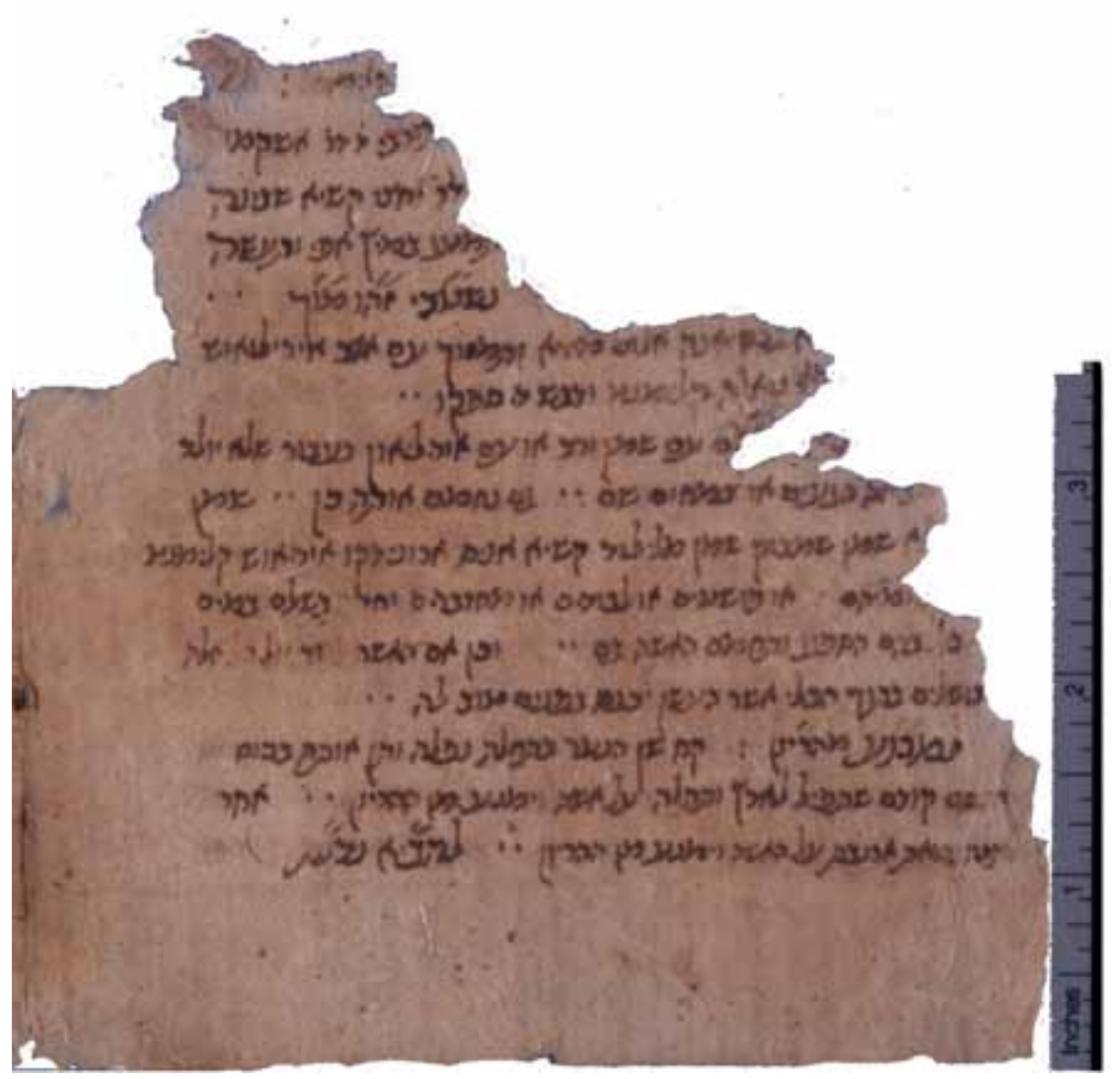

Figura 2. () AMGi, Col·lecció de documents hebreus, HB27a r. 
${ }_{20}$ Una pócima de anacardo que incrementa la memoria y aumenta el saber y el ingenio ${ }_{21}$ y aleja la amnesia. [...] rompe la fuerza de la flema, fortalece el estómago y es provechoso ${ }_{22}$ para todos los miembros que estén fríos. Hay que asegurarse de guardarse de todas las fuerzas ${ }_{23}$ del frío, y es de gran provecho, y el corazón además mejora. Y este proceder es bueno. ${ }_{24}[\ldots]$ coge jengibre, màstec, galanga, canela, espic, anís, el peso de $9{ }_{25}$ peso melgoires, cada uno con un peso de escila, que es un jugo de hierbas que comen ${ }_{26}$ los camellos, anacardo, es decir anacard[i], y utiliza solamente el jugo y [... $]_{27}$ cogerá pinzas candentes y tratará con ellas hasta que salga $[\ldots]$ [coge cuatro] $[\ldots]_{28}[\ldots]$ y con las cosas hermosas: coge ment, cuyo nombre es $[\ldots]_{29}[\ldots]$ peso, incienso [...], cardamomo [...].

$[\ldots]$

[31b 2v] $[\ldots]_{1}[\ldots]$ cuatro mujeres estériles: Sara, Rebeca y Raquel y L[ea]. Esto abre el útero de tal mujer ${ }_{2}$ en tal noche y así sea la voluntad del Señor de los ejércitos para contigo, Amén, Amén. Y yacerá su marido con ella ${ }_{3}$ y quedará encinta. Otro remedio: Coge estómago de conejo y bébalo el hombre y la mujer con vino a la hora de acostarse ${ }_{4}$ y vigilarán la higiene durante 15 días, y si el conejo es macho, engendrará un varón y al revés.

\section{[reclamo:] Contra el dolor de la matriz}

[23b r] 1 Contra el dolor de la matriz: ${ }_{2}$ Coge romani[no] y poliol e higos secos, una porción de rubia, anís y semilla de hinojo ${ }_{3}$ y cuece todo con vino blanco, y bébalo y sanará.

Sobre el dolor de la matriz y su localización: ${ }_{4}$ Para la matriz bien haya salido o bien no haya salido (de su lugar), coge una hierba llamada lešcodinš ${ }^{10}$ que crece ${ }_{5}$ en los jardines o en el campo, cuya hoja es amarilla y hallarás de esta hierba dos tipos: el excelente ${ }_{6}$ junco que es liso, y coge el vegetal y cuécelo bien [atado] con un cordón de hilo de lienzo que no ${ }_{7}$ esté cocido ni mondado y remueve el vegetal hasta juntarse lo de arriba con lo de abajo, [hazlo] dos o 4 [veces], y después ${ }_{8}$ se sahumará la mujer por abajo dos veces al día y esto lo hará [durante] tres días y sanará. Esto ${ }_{9}$ es de comprobada eficacia. Y a continuación hágase un ungüento: Coge ajenuz y machácalo ${ }_{10}$ y extrae de él el jugo. Y toma grasa de gallina blanca y ponla en un recipiente sobre el fuego y caliéntala ${ }_{11}$

${ }^{10}$ Voz no identificada. 
20

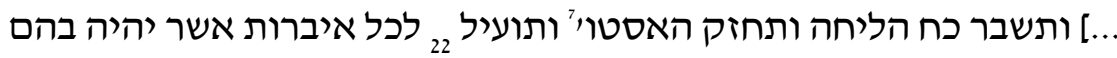

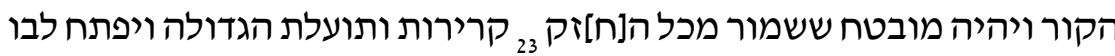

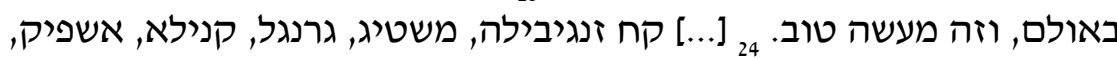

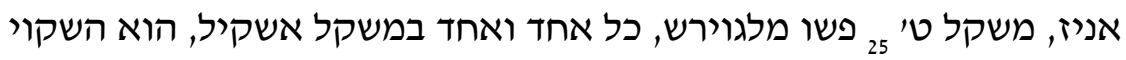

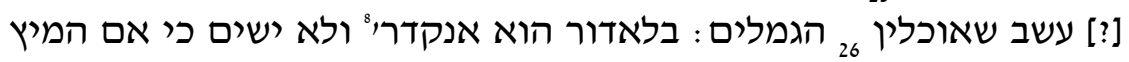
ו....] כבד [...] ועם הדברים השפרים: קח מנט, שמו [...] ${ }_{29}$ [...] פשו, לבונה [לח [...] קרדמומו

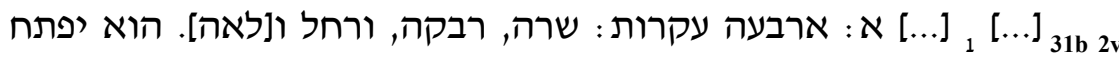

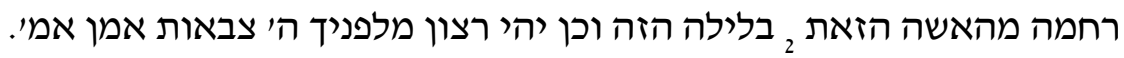

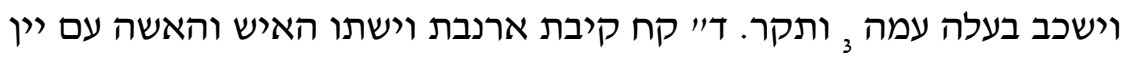

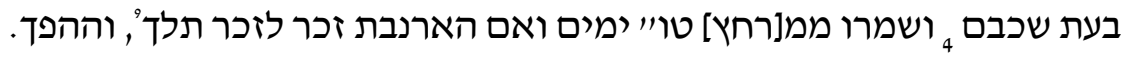

לכאב האם

23b r ואניס, וזר[ע] שומר, ובשל הכל ביין לבן ותשתה ותרפא]ה].

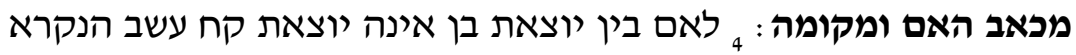

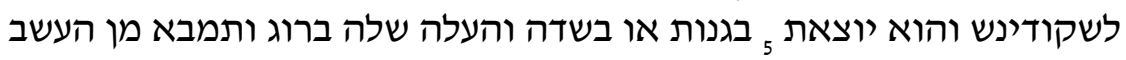

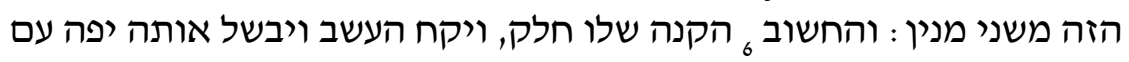

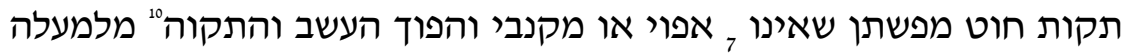

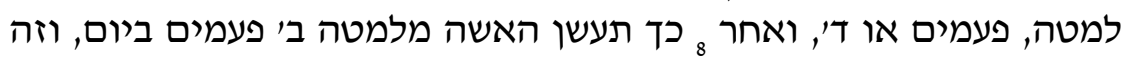

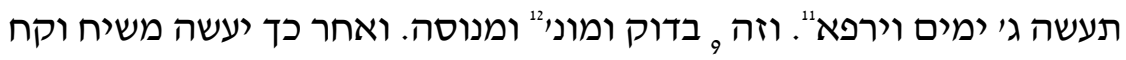

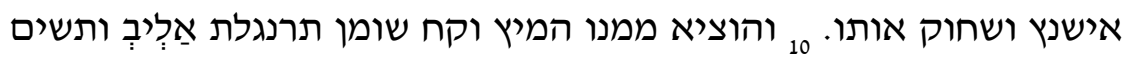

$$
\begin{aligned}
& { }^{7}{ }^{8} \\
& 8 \text { אנא קרטומאי } \\
& 9 \text { תלד } \\
& 10 \text { בהתקוה } \\
& 11 \\
& 12
\end{aligned}
$$




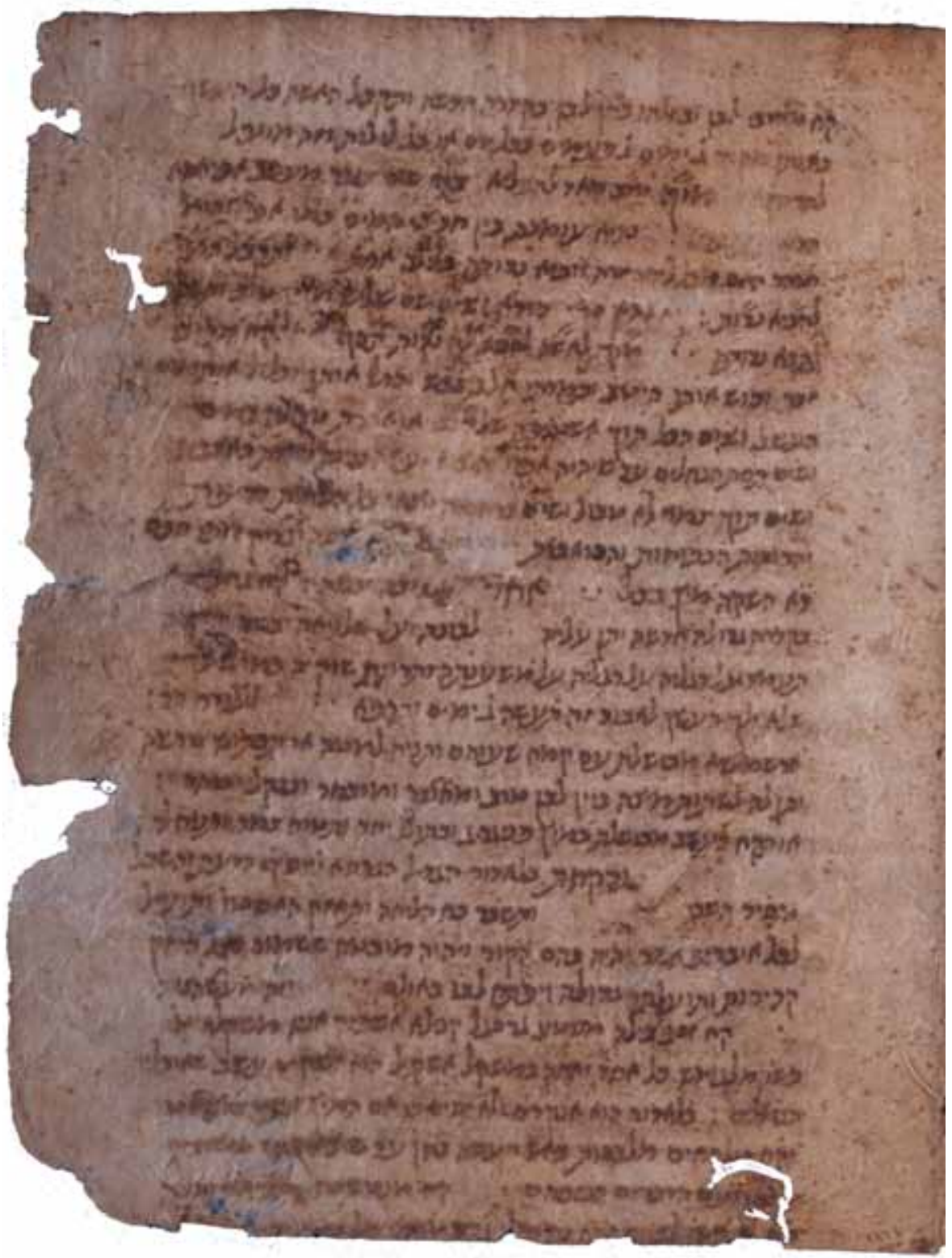

Figura 3. (C) AMGi, Col·lecció de documents hebreus, HB23a r.

SEFARAD, vol. 74:1, enero-junio 2014, págs. 33-74. ISSN: 0037-0894. doi: 10.3989/sefarad.014.002 


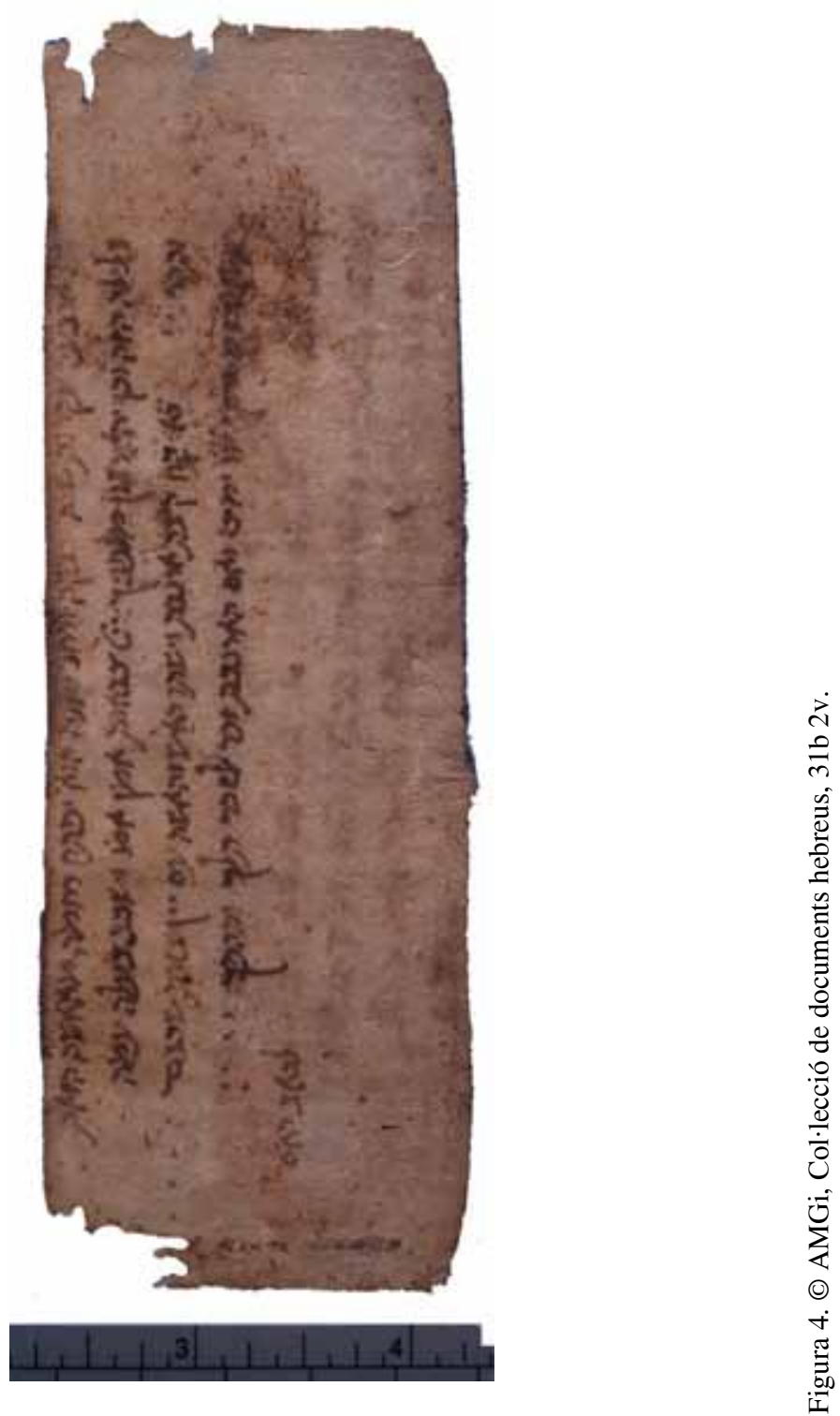


hasta que esté derretida y añade un poco de cera, un poco de bori ${ }^{11}$ que es llamado ${ }_{12}$ sarcocola, un poco de màstic y un poco de alcanfor, y machaca todo esto excepto la cera y mezcla ${ }_{13}$ con el vino de ajenuz y con zumo de fenogreco, y unta la matriz por dentro y se absorberá la matriz si esta ha salido, ${ }_{14} \mathrm{y}$ su vientre se volverá liso de abajo hacia arriba y se curará la matriz y volverá a su sitio. Y esto haz ${ }_{15}$ después, un sahumerio de hierbas, una vez se sahúma por la mañana y una vez por la tarde durante cuatro ${ }_{16}$ o cinco días y sanará con la magnanimidad del Señor. Y si no puedes extraer el jugo del ajenuz, mezcla ${ }_{17}$ con el vino agua y esto es de comprobada eficacia.

${ }_{18}$ Sobre el dolor de los riñones. ${ }_{19} \mathrm{Y}$ estos [son]: El colon se desplaza a causa del dolor de los riñones. Si el dolor de los riñones persiste y no viene de otro ${ }_{20}$ lugar, y el colon se mueve de un lado a otro, [hay] un remedio. Es conveniente para él darle leche de burra ${ }_{21}$ con dragontea, y leche de cabra, que es buena [...] y comerá cocorbita ['calabaza'] y malva, bortolaiga. ${ }_{22}$ Y se preparará una lavativa con jugo de cocorbita ['calabaza'], verdolaga, una porción de sil·li, viola, ${ }_{23}$ regalèssia. Si por casualidad encontraras terebinto, mézclalo con aceite de violad, aceite de clemátida flámula, ${ }_{24}$ aceite de almendra. Y si el dolor es accidental, ${ }_{25}$ coge aceite de laurel, aceite de anet, camomila y semejantes [...] y jugo de ${ }_{26}$ hierbas como mirra, api, camomila. Y dice Galeno sobre la pérdida de sangre a causa del dolor ${ }_{27}$ de los riñones, que es muy bueno [...], ${ }_{28}$ mijo es provechoso para los riñones y para el intestino [...] deshace el cálculo y esto es efectivo contra el dolor de riñones, ${ }_{29}[\ldots]$

[23a v] 1 o para curar un escroto viejo: [coge] granos de mijo y api cocido sobre las brasas y machacados con mantequilla y fája[lo] ${ }_{2}$ por debajo del vientre y orinará. [...]. Otro remedio: una unción con aceite de laurel, marsiatón $^{12}$ y aragón $_{3}^{13}$ en la parte de debajo del vientre. Otro remedio: Coge agaric - un cuarto de siclo- y móndalo y fluirá ${ }_{4}$ la orina y se calmará el dolor de los riñones y se estabilizará su presión al estimular la orina. ${ }_{5}$ Se dice que son las bayas del anagall las que destruyen el cálculo, y las legumbres hacen que se destruyan los cálculos y eli-

\footnotetext{
${ }^{11}$ Podría tratarse de borago officinalis, un sustituto regional para la sarcocola de Africa.

${ }^{12}$ Voz no identificada. Podría tratarse de una palabra compuesta, ver glosario s.v.

${ }^{13}$ Se trata de un compuesto, cf. Trotula, 125.
} 


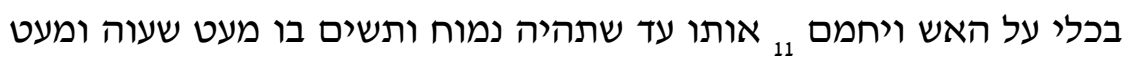

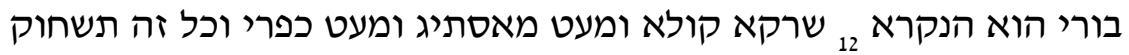

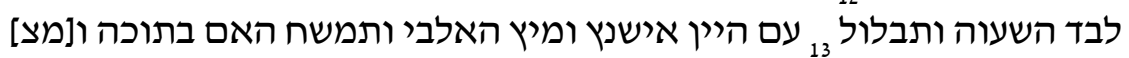

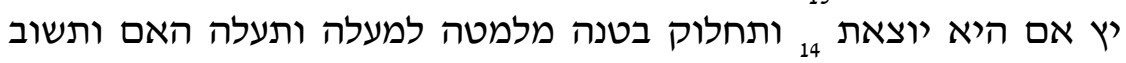

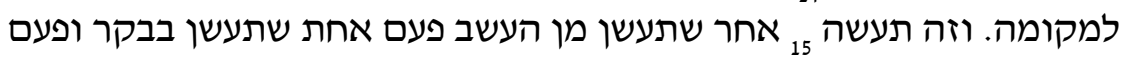

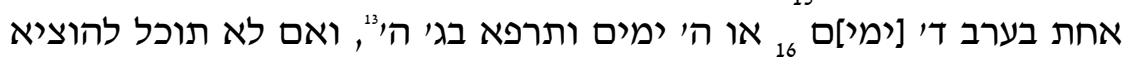

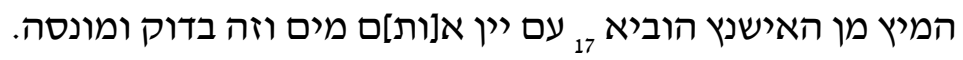

18

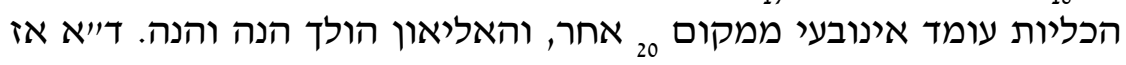

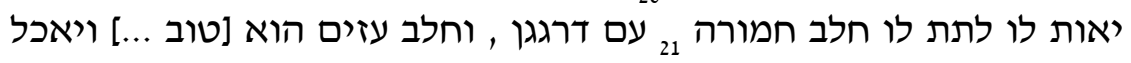

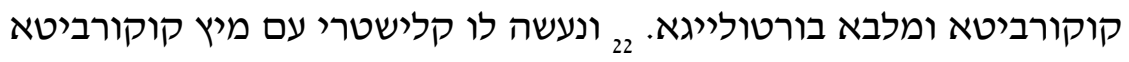

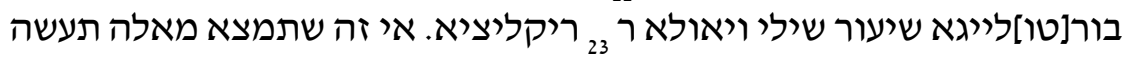

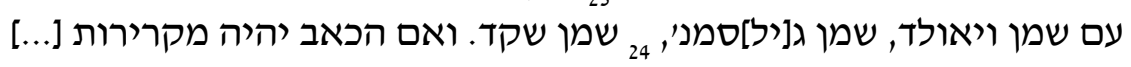

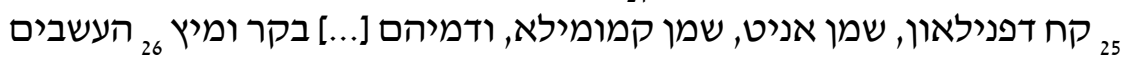

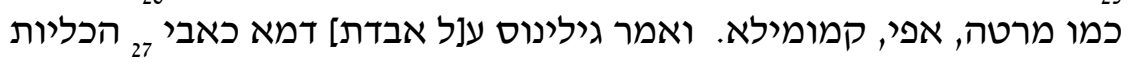

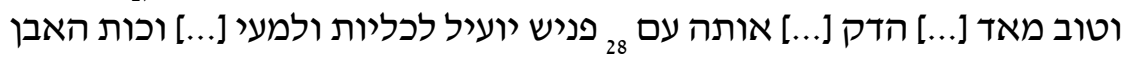
ויוע]יל לכאב הכליות]

או.... [123av

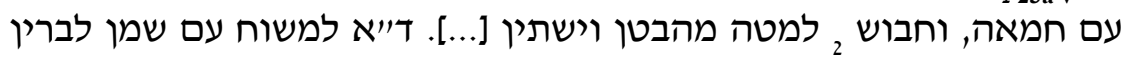
ומרסיאטון וארגון

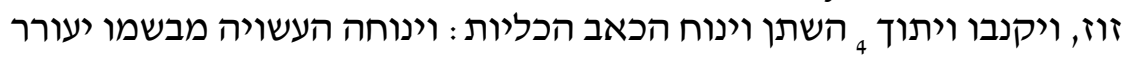

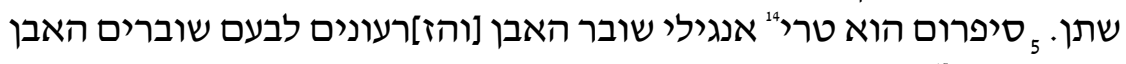

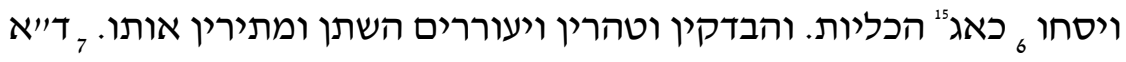

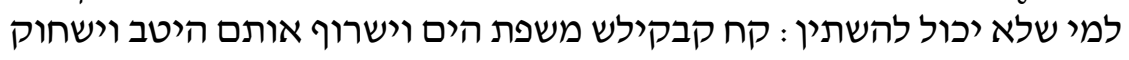

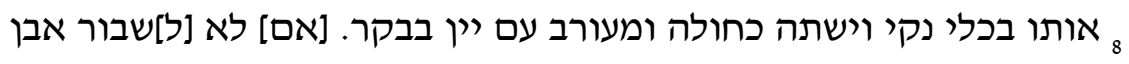

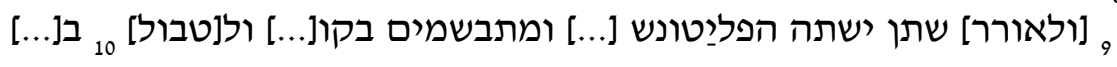

$$
\begin{array}{r}
13 \\
14 \\
15 \\
\text { בגדולת השם } 2 \text { כאב }
\end{array}
$$


minan ${ }_{6}$ el dolor de los riñones. La observación, la higiene y la estimulación de la orina lo liberan [del dolor]. 7 Otro remedio para el que no pueda orinar: Coge cauquillas ['conchas'] de la orilla del mar, y tuéstalos bien, pulverízalos ${ }_{8}$ en un recipiente limpio y bébase cuando esté indispuesto mezclado con vino por la mañana. Si no se rompe el cálculo ${ }_{9}$ y para estimular la orina, beba agua de rosas y perfúmese con $[\ldots]_{10}[\ldots]$ los riñones, lavanda de Salónica [...] y para el hígado y el bazo espica- ${ }_{11}$ nard es bueno y azafrán. Y dicen que son provechosas [¿las lentejas de agua?], es decir los fesoles. También es buena la semilla de ${ }_{12}$ hinojo y regalèssia y hierba de perejil para que desaparezca [...]. Una pócima coagulante ${ }_{13}$ como romero [?] es buena para preparar una lavativa.

Libro de los antídotos ${ }_{14}$ que añade [...] y unta la espalda con este jugo, y el resto de [...] aceite de camomila. ${ }_{15}$ Se limpiarán y se calentarán con espic, esquinant, anís [...].

${ }_{16}$ Cuando disminuye el apetito sexual: ${ }_{17}$ Coge cuatro uvas, y así [...] de cordero, higos maduros [...] cocidos ${ }_{18}$ [que] ablandan [hasta] los mismísimos huesos. Y también naps y habas frescas [...]. Si quiere ${ }_{19}$ preparar él mismo este electuario, ha de combinar con las habas y materias semejantes ${ }_{20}$ una mezcla de [materias] ácidas y la seba fresca, el grano, que es mejor que carne fresca, ${ }_{21}$ y el seso de la cabeza y la yema de los huevos, y la doble cantidad de nueces y semejantes y sanará. ${ }_{22}$ La semilla fresca del esquinant, una onza de jengibre [...] con vino blanco y tinto: ${ }_{23}$ cost, safrá[n], mastuerzo, semilla de ortiga, anís, semilla de lino $[\ldots]_{24}$ Una comida y un remedio apropiado para esto es por ejemplo espárrago, ${ }_{25}$ oruga, api, acoro y semejantes. Es evidente que las recetas sencillas como estas mencionadas ${ }_{26}$ y semejantes [...] serán provechosas para ello.

El ungüento de Yoḥanán de Damasco: ${ }_{27}$ Este ayuda a aumentar mucho [el deseo] del coito [...] y se lavará ${ }_{28}$ pimiento largo -40 dracmas-, [20] semilla de cebolla [...] semilla de orenga y semilla de ortiga. ${ }_{29}[\ldots]$

[27a r $][\ldots]_{1}[\ldots]$ coge canela $[\ldots]$ de la medida para $[\ldots]$.

Otro remedio: cinamom(o), ${ }_{2}[\ldots]$ safrá[n], jengibre, murta, menta, calement, orégane, casia, 39 dracmas de granos de pimienta blanca o negra, ari, ortiga, quilla de clavo de especia, gala[n]ga, raíz ${ }_{4}$ del cardo corredor, pelitre, cardomom[o] -de las raíces, y jugo de naps 3 dracmas, y espésalo con almendras, ${ }_{5}$ envuélvelo en zumaques limpios y aclarados, panis- 19 dracmas y miel de saúco. 


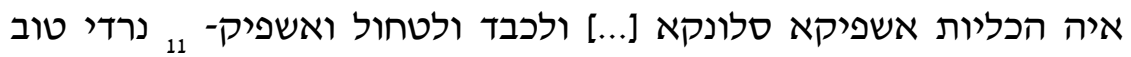

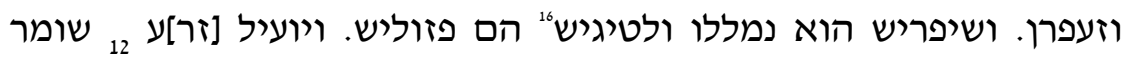

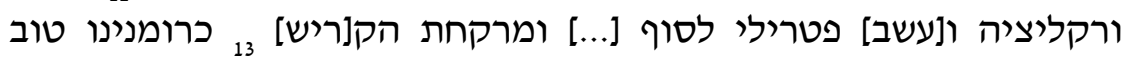
להפשיר קליסטרי.

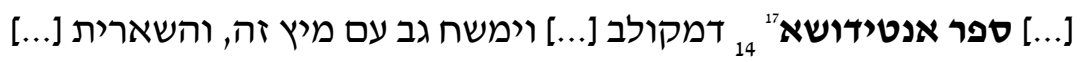

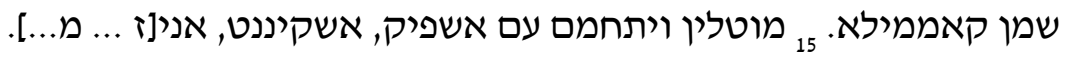
ממעוט המשגל : ${ }_{16}$ קח די עונב,י, וכן [... ] השה מצמלים [מוחלים ...]

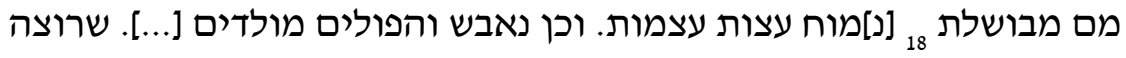
${ }_{19}$

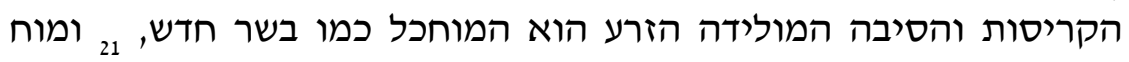

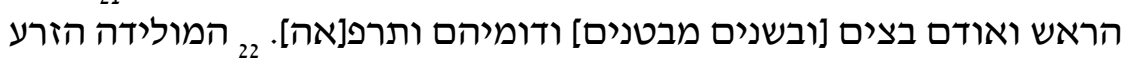

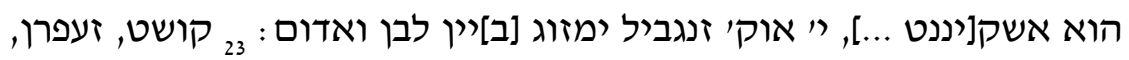

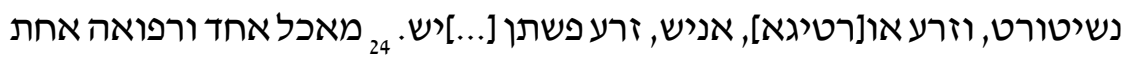

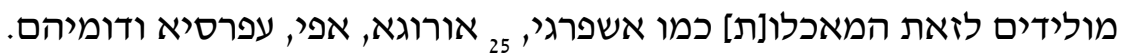

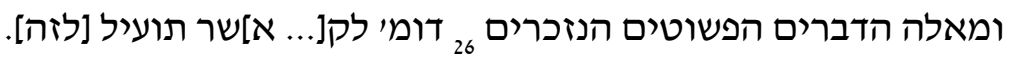

מרקחת יוחנן מדמשק: 27 זה עוזר להרבות [המשג]ל מאד [...] יטבול

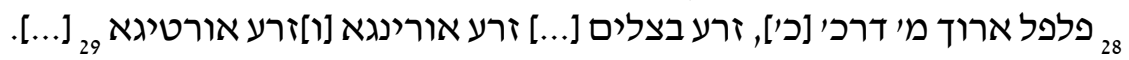

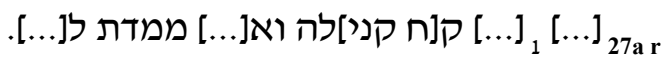

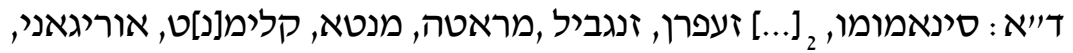

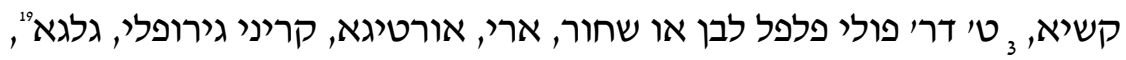

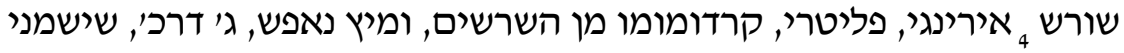

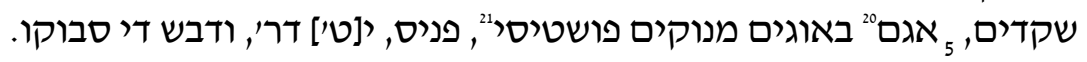

$$
\begin{aligned}
& 16 \text { לינטיגיש? } \\
& 17 \\
& 18 \text { ענבים } \\
& 19 \text { גלנגא } \\
& 20 \text { אגמן } 20 \\
& 21 \text { פושטים }
\end{aligned}
$$




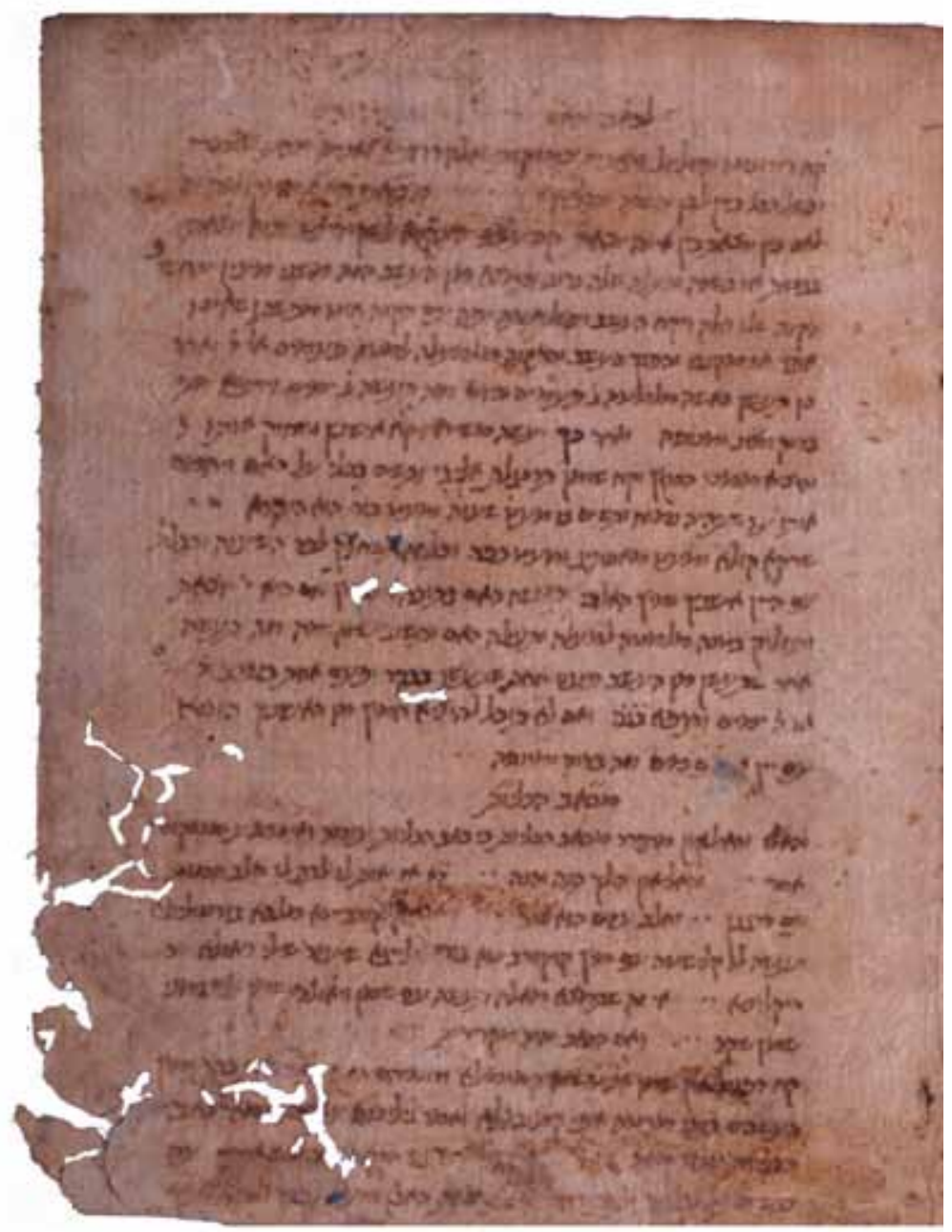

Figura 5. (c) AMGi, Col·lecció de documents hebreus, HB23b r.

SEFARAD, vol. 74:1, enero-junio 2014, págs. 33-74. ISSN: 0037-0894. doi: 10.3989/sefarad.014.002 


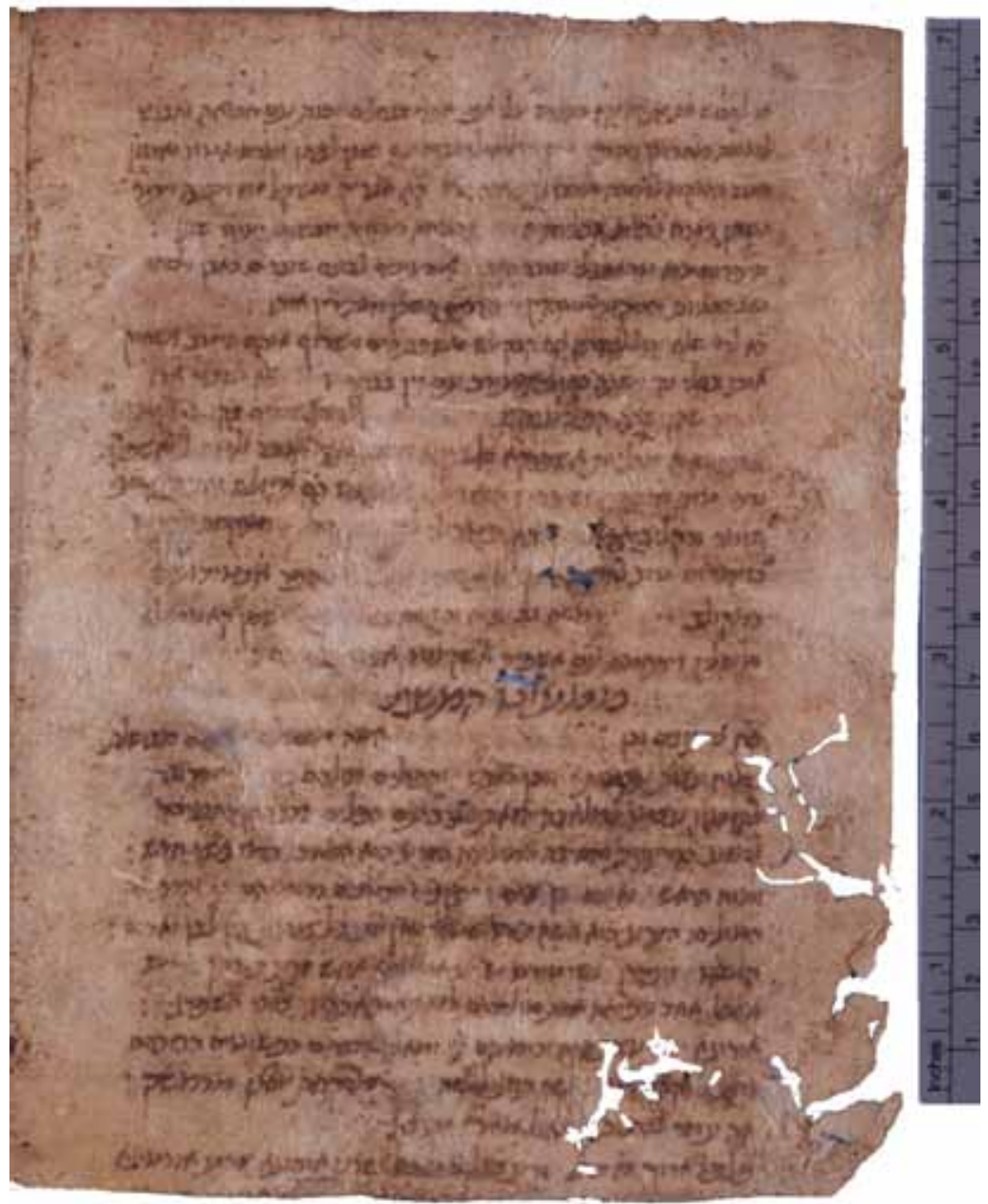

Figura 6. ( ) AMGi, Col·lecció de documents hebreus, HB23a v. 
${ }_{6}$ Otro [remedio]: Semilla de lino, anís, panis aceitoso [...], sauc, y cardo corredor, galanga, calement ${ }_{7}$ media dracma, y miel de saúco. También ayudará la leche de vaca y los dátiles, ${ }_{8}$ harina de cebada con miel y cinamom[o], clavo de especie, galanga -15 dracmas. Un sirope bueno para esto es ${ }_{9}$ murta, anís, semilla de ortigas, galabasí ${ }^{14}$, menta, calement, orégano-20 dracmas-, pasas ${ }_{10}$ limpias -5 dracmas-; todo esto cuécelo con 12 litras $^{15}$ de agua hasta que se haya reducido a la mitad, y prénsa[lo] y añádele ${ }_{11}$ miel como su medida en partes iguales y cuécelo de la siguiente manera: al comienzo de la cocción añade ${ }_{12}$ safrá[n], jengibre, galanga, clavo de especie, pimiento largo, cinamom [o], cardo corredor, ${ }_{13}$ cardomom[o], cost un peso de 4 dracmas, todo esto pulveriza y envuélvelo en un trapo. En caso de que el coito falle ${ }_{14}$ por el calor o por la sequedad, todos los tratamientos y comidas mencionados más arriba previenen de ello. Y se le recete ${ }_{15}$ para su alimentación leche de vaca y pescado fresco, bleda, es decir acelgas, calabaza y semejantes. ${ }_{16}$ Y prepárese un recipiente apropiado con materias secas y húmedas y con zumo de cocor[bita, 'calabaza] a fin de que vuelva ${ }_{17}$ a tener vigor. Y [si] se enfriara, repítase con una mezcla apropiada.

Sobre la prolongada erección del pene: ${ }_{18}$ si se prolonga por esto, que no repita sin deseo y placer el coito. He aquí que el que padece ${ }_{19}$ de la enfermedad llamada purgisimus ${ }^{16}$, su causa son los gases gruesos y la flema fuerte, ${ }_{20} \mathrm{y}$ se contagia [cuando] se adultera al principio. Y dice Galeno que todo tratamiento o alimentación aumenta [el deseo] del coito. Hay que estar al acecho de ${ }_{21}$ esta enfermedad. Y para ayudarle es conveniente darle cosas distintas para cambiar y enfriar el humor. ${ }_{22}$ Ha de ser untada la columna vertebral y [...] y el orificio y los testículos con zumo de solano y zumo de verdolaga ${ }_{23}$ y lentejas de agua y sempreviva. Y [si] la pasión llega al pene y le excita al placer ${ }_{24}$ del coito, coja además opi y càmfora, que son útiles para esto, con aceite de rosas a medidas iguales.

$[\ldots]$

[27b v] $[\ldots]_{1}$ coge hierbas amargas, la parte buena de arriba, mézclalas con agua, [...] májalas con pienso, ${ }_{2}$ no el blanco, que no se deshace bien y mezcla todo, y aplícalo sobre él [...]. ${ }_{3}$ [Si] está desfallecido por padecer obesidad, disuelve cera juntamente con $[. .$.$] . Y después de esto desaparecerá gradualmente el tumor { }_{4}$ con

\footnotetext{
${ }^{14}$ Cat. carabassí 'semillas de calabaza', ver DLCIEC s.v.

${ }^{15}$ Peso romano $=358,21$ gr.

${ }^{16}$ Enfermedad venérea.
} 
אחר : זרע פשתן, אניס, פניס שישמני, סבוק ו[איר]ינגיש, גלנגא, קלימנט

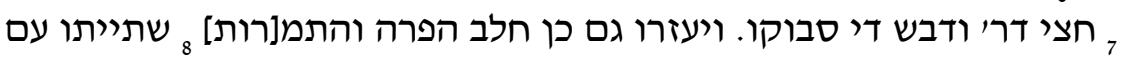

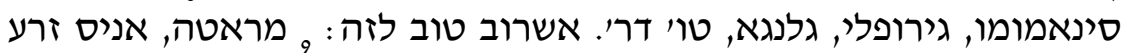

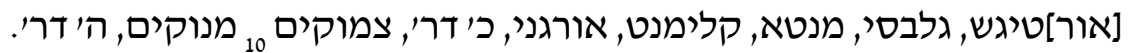

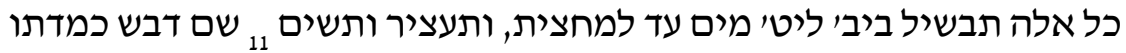
בשוה, ותבשל כמו כן, ובתחלת הבשול תשים שם 12 זעפרן, ז[נגביל], גלנגא,

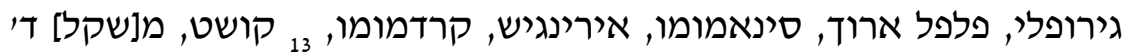
דר', כלה אלה תכתוש לאבק ותקשור בבגד. ואם הזווג יעדר 14 בחום וביבשות,

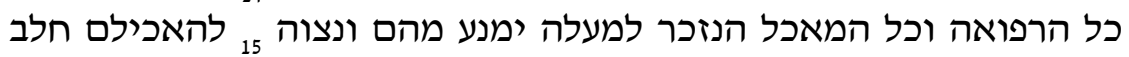

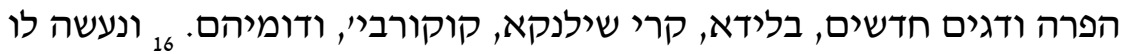

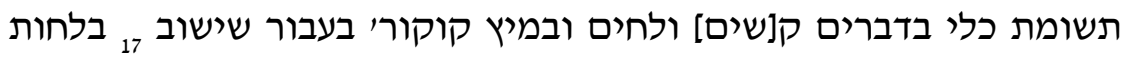

והחום יתקרר וישוב במזג נכון.

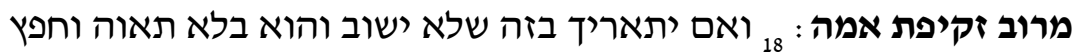

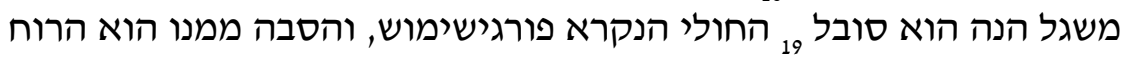

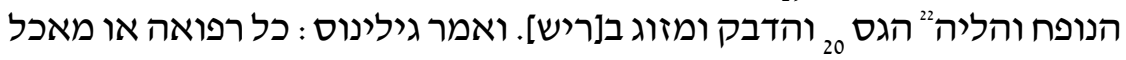

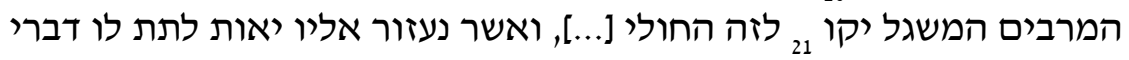

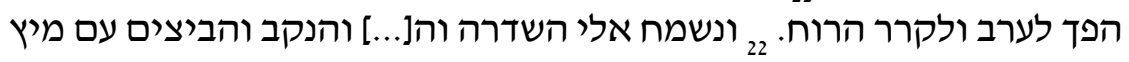

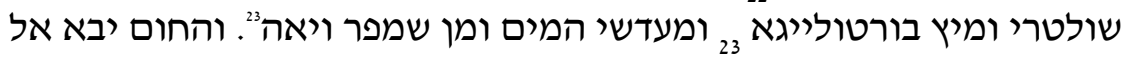

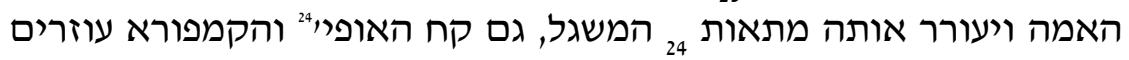
לזה עם שמן וורד למשורו אורור מתורות

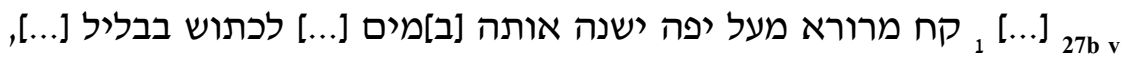
2 לא הלבן ושאינו ט[ובה] וערוב הכל, ותשים עליו [...].

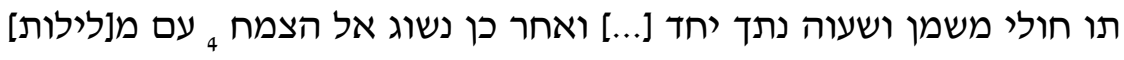

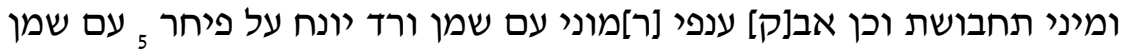

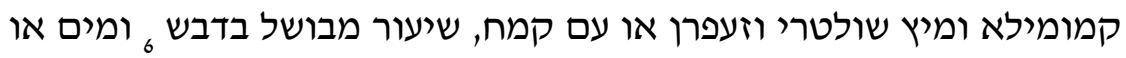
פולנים] מבושלים [...]. תחבושת זה טוב לנהחזיק] כף , בביצים: רושו [.

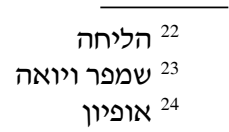


melilot y una especie de emplasto, así como polvos de vástagos del granado con aceite de rosas; [déjese] reposar en una vasija ${ }_{5}$ con aceite de camomila y jugo de solano y safrá $[n]$, o con harina de cebada cocida con miel ${ }_{6} \mathrm{y}$ agua o habas cocidas [...]. Un emplasto que es bueno para fortalecer el pubis ${ }_{7}$ con los testículos: [granada], [... vino] tinto y blanco, [...] raíz de malva y su semilla ${ }_{8} 5$ dracmas de esto 3 [...] y aceite de rosas $-1 \mathrm{zuz}^{17}-$; y si el tumor ${ }_{9}$ está casualmente herido, pon uvas pasas, habas, huevos cocidos y melilot ${ }_{10}$ con viruta de [...], y yema de huevo y harina de trigo [...] después [prepara] ${ }_{11}$ un clister [enema], [...], un huevo, habas pulverizadas y legumbres, camomila -6 dracmas, ${ }_{12}$ incienso, mirra [...], comino - 1 dracma, grasa de los riñones de la gacela, cera de abeja [y] aceite lubricante, ${ }_{13}$ tuétano de ternero [...] yema de huevo, y elabora una unción y un emplasto. ${ }_{14}$ Otro remedio: Una unción [...] y esto es mejor para el eczema de los testículos que una sangría ${ }^{18},{ }_{15}$ y la parte de [...], y seso de [...], aceite de rosas -una onza y 10 de enebro, ${ }_{16} 10$ dracmas de cera de abeja [...] dracmas de casia, semilla de rosas -2 dracmas, y elabora un buen zumo. ${ }_{17}$ Otro remedio: enebro [...] -7 dracmas-, càmfora-2 dracmas-, opi-una onza-, mézclalo con zumaque. Y si ${ }_{18}$ los testículos están heridos por [...] o por [...] o empequeñecidos prepara un ungüento de alumbre y de gatell. ${ }_{19} \mathrm{Y}$ si hay ahí hernias, coge rasín con aceite de rosas y con la yema de huevo y elabora un ungüento.

${ }_{20}$ Para la hinchazón de los testículos: Coge puerros, es decir porros, cuécelos en aceite de oliva o en grasa de cerdo, ${ }_{21}[\ldots]$ y ponlo sobre el lugar hinchado y úntalo bien con esto. ${ }_{22}$ Coge grasa de cerdo, y cera y su sangre, y tuétano de los huesos, y leche de cabra, de oveja y de vaca y mezcla y derrite ${ }_{23}$ todo sobre el fuego y unta de esto caliente [...].

Para el que tiene las entrañas [dolidas] ${ }_{24}$ que no se mueva mucho por la hernia. Una placa de plomo es [horadada] con algo como

[23b v] 1 casia, madera de cedro, llamada madera de aloe, safrá [n], macis, semilla de api, ameos de cada ${ }_{2} 3$ granos, menta -7 granos de peso. Y macháquense las especias bien y pásense por un cedazo o ${ }_{3}$ por un tamiz muy fino y cúbrase con miel, de la que se haya retirado su espuma y tómese la cantidad de una

\footnotetext{
${ }^{17}$ Moneda de plata de $1 / 4$ de šéquel (3,5 gr).

${ }^{18}$ El texto dice: 'que el temperamento sanguíneo y la sangre'.
} 


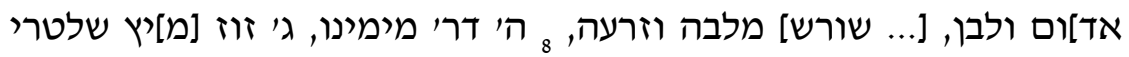

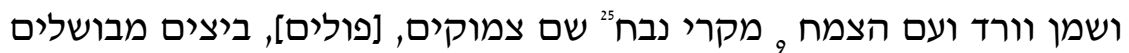

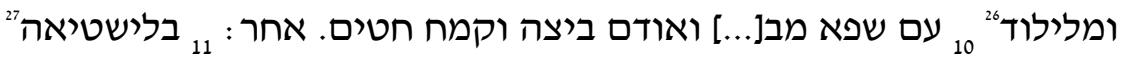

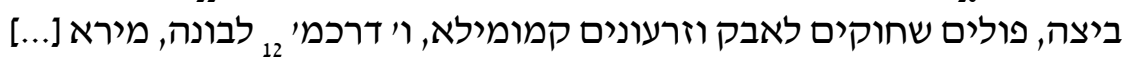

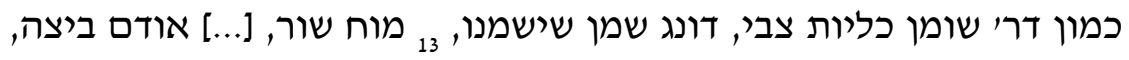

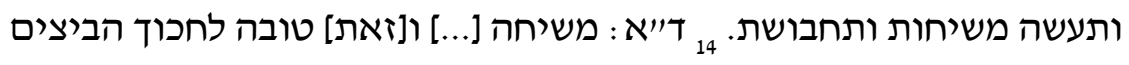

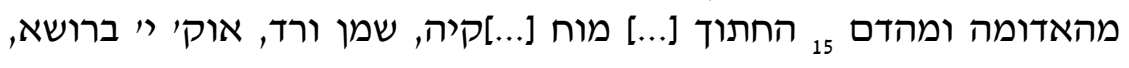

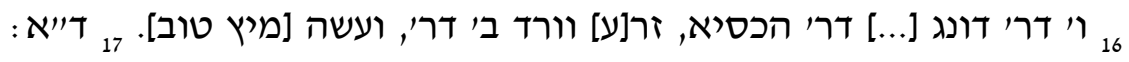

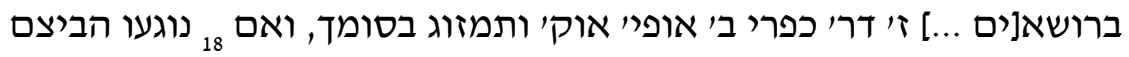
מ[...] מהזיעק, תעשה משיחה מאלום ומגטלאיא. רסין עם שמן ורד ועם אודם ביצה ועשה משת משיחה ומגלה.

20

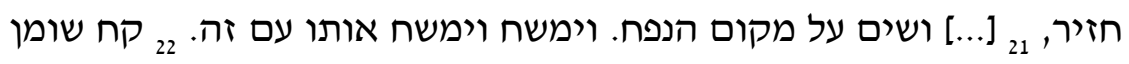

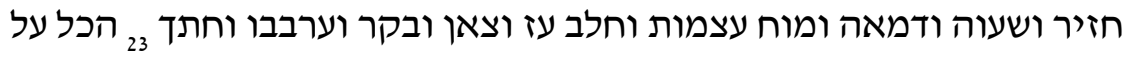

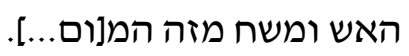

למי יש הוא קרבין:

[...] בשוב כמו למי ימוא

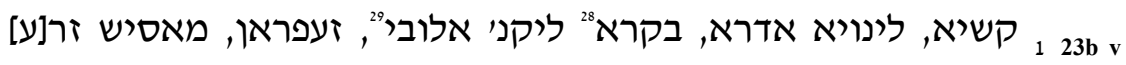

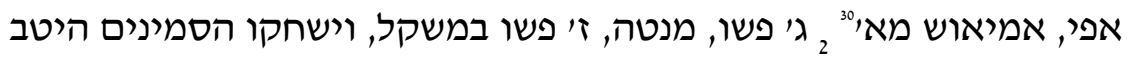

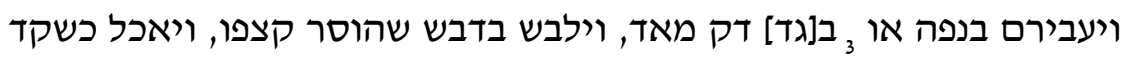

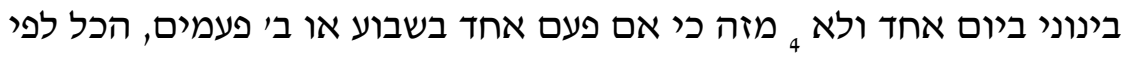

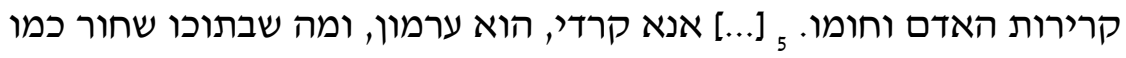

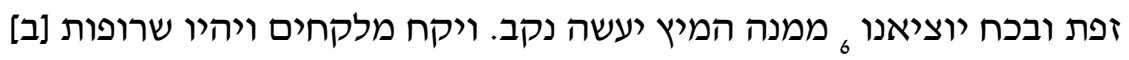

$$
\begin{aligned}
& 25 \\
& 26 \text { מלילות } 25 \\
& 27 \text { קלישטירא } 26 \\
& 28 \\
& 29 \text { ליקנוס אלואי } \\
& 30
\end{aligned}
$$




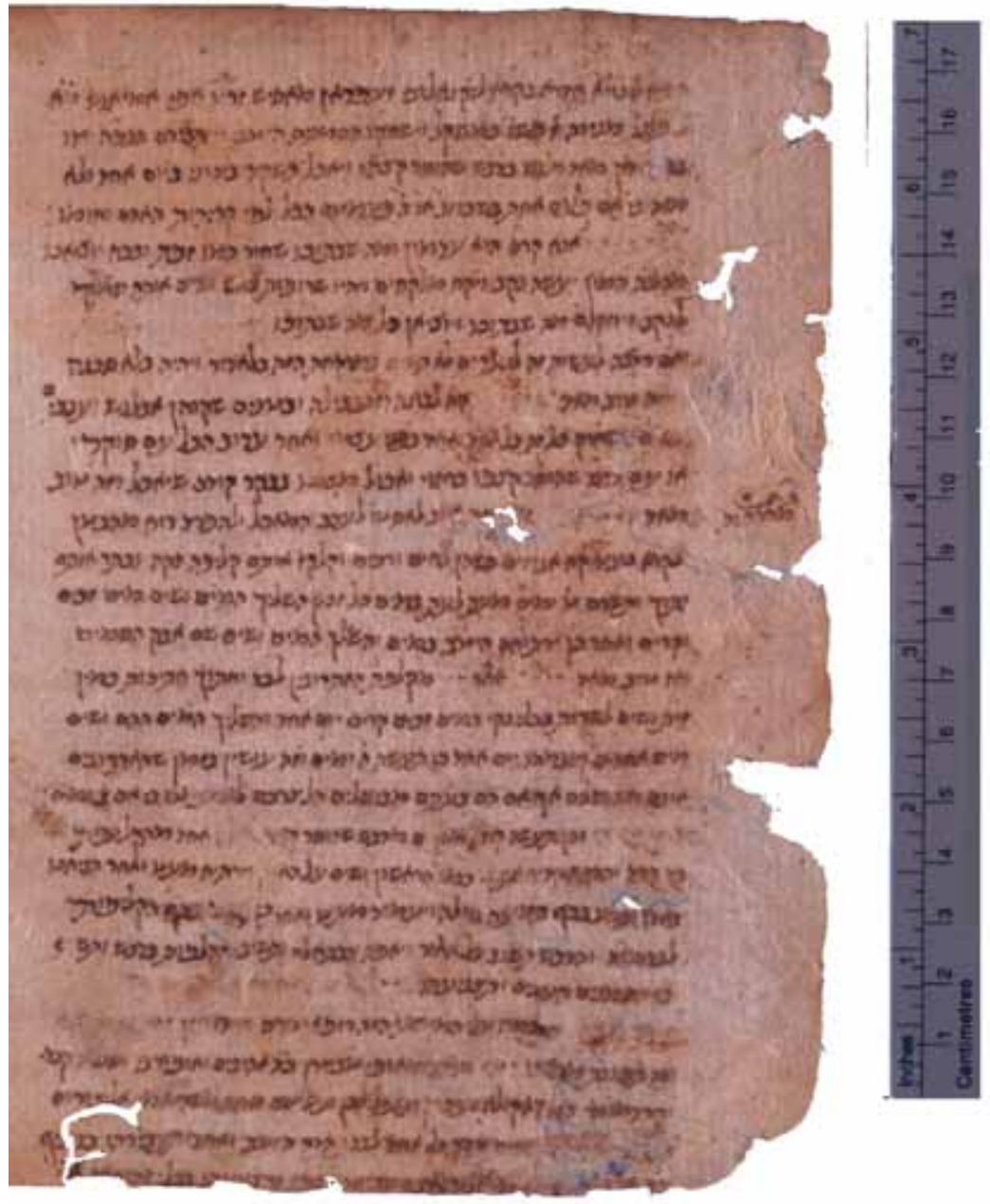

Figura 7. () AMGi, Col·lecció de documents hebreus, HB27a r.

SEFARAD, vol. 74:1, enero-junio 2014, págs. 33-74. ISSN: 0037-0894. doi: 10.3989/sefarad.014.002 


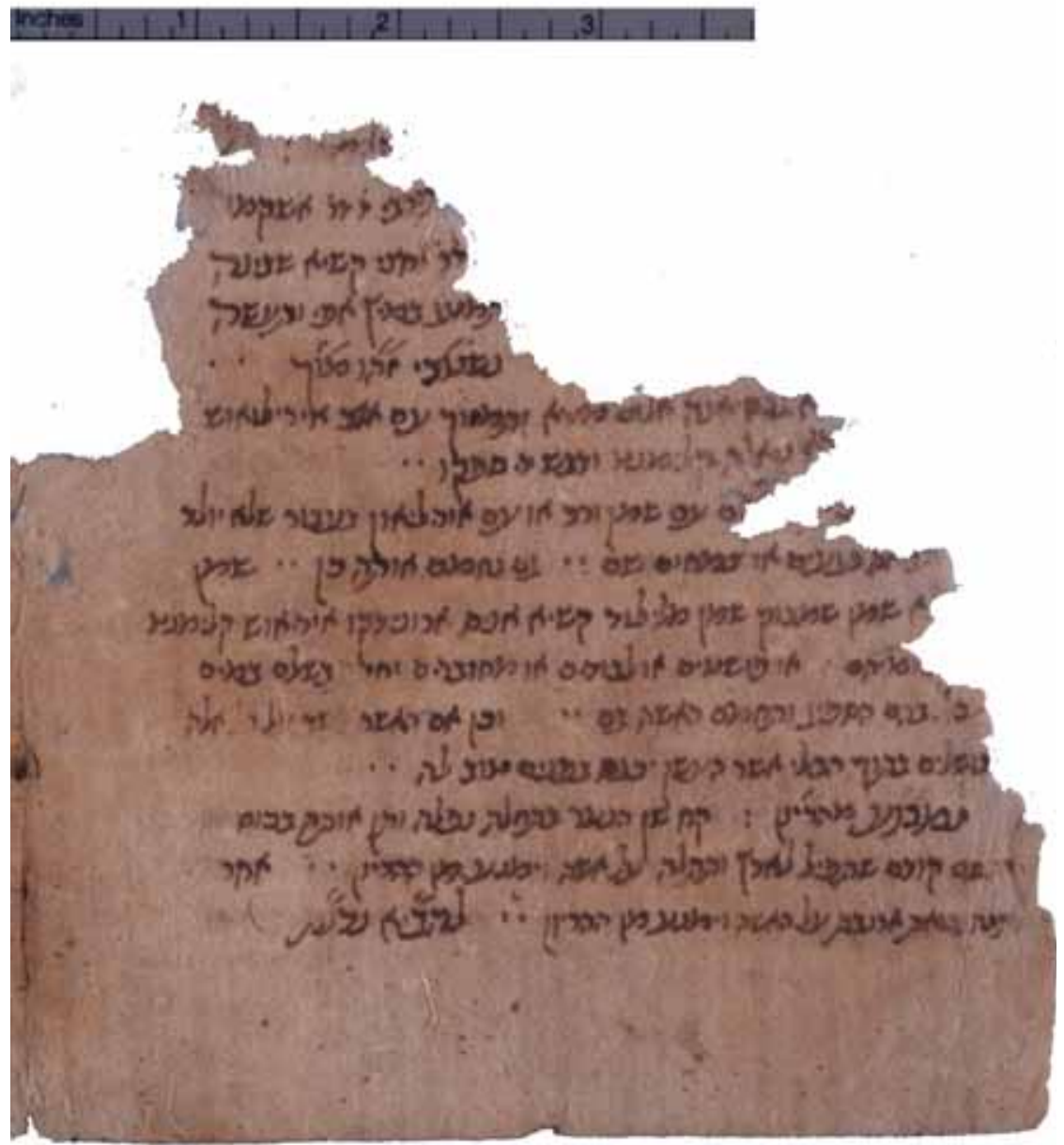

Figura 8. () AMGi, Col·lecció de documents hebreus, HB27b v. 
almendra mediana en un día y lo ${ }_{4}$ máximo una vez por semana o dos en total según el frío del hombre y su calor. ${ }_{5}[\ldots]$ anacard $[i]$, es decir castaña, y lo que hay en su interior negro como el alquitrán, y con fuerza extráigase ${ }_{6}$ de ella el jugo haciendo un agujero. Cójase unas tenazas ardientes y pónganse cerca ${ }_{7}$ del orificio y se calentará todo su interior y expulsará todo lo que hay adentro. ${ }_{8} \mathrm{Si}$ se quiere aplicar esto a niños no ha de meterse en este ungüento anacardo, [así] no será peligroso ${ }_{9} \mathrm{y}$ es muy bueno [...]. Coge incienso y jengibre, nueces que se llaman avellanes, y uvas ${ }_{10} \mathrm{y}$ arilos, y pulveriza todo esto uno por uno en la misma relación y a continuación mezcla todo con azúcar ${ }_{11}$ o con miel, de la cual se ha retirado su espuma como es debido; tómese de esto por la mañana antes de comer y esto es muy ${ }_{12}$ bueno. [...] [las hierbas amargas] ${ }^{19}$ son buenas para el estómago mezclándolas con la comida, [pues] alejan el aire del vientre, ${ }_{13}$ que es llamado fugat. Coge nueces tiernas y frescas y [pela] la cáscara fina, córtalas ${ }_{14}$ por el medio, y cambia durante 9 días de un día para otro el agua echando el agua y poniendo agua limpia ${ }_{15} \mathrm{y}$ fría. Después que las hayas humedecido bien con agua, echa el agua y añade el polvo de las especias, ${ }_{16}$ ya que [esto] es muy bueno. Otro remedio: [Coge] solamente monda de las cidras, y córtala a trozos [del tamaño] de ${ }_{17}$ una aceituna y pon[las] en remojo en un recipiente limpio con agua pura y fría durante un día y echa estas aguas y pon ${ }_{18}$ agua fresca y ha de reposar un día. Y así se hará esto durante 5 días. Esto ha de hacerse cuando las cidras ${ }_{19}$ no estén cocidas. Pero si en ese momento ya estuvieran todas cocidas, no necesitan reposar más que 2 días. ${ }_{20}[. .$.$] y así has de hacer: Coge 3$ partes de miel sin espuma y una [parte] de mondas ${ }_{21}$ a partes iguales y la miel aclarada como al principio, ponlo sobre el fuego, y hazlo hervir un poco y después déjalo ${ }_{22}$ sobre la tierra. Y mueve con la mano fuertemente, y que pose un poco. Después saca con la mano las mondas, ${ }_{23}$ solamente estas y la miel pon sobre el fuego, y cuézase como al principio y vuélvase a repetir las mondas con la miel y añade ${ }_{24}$ las buenas especias y consérvalo. ${ }_{25}[\ldots]$ y acordaron sobre lo expuesto los médicos de Persia y [...]. ${ }_{26}$ Esto le liberará de su aflicción: coge marrubi y opi de Tebaria -24 ducados, euforbio, y [...] ${ }_{27}$ y cardamom[o], azucena silvestre, safrá[n], pimiento blanco, pelitre, rosas, sicómoro [?], eléborom. ${ }_{28}[\ldots]$ pulveriza cada uno muy bien, y después cúbrelo con un paño fino ${ }_{29}[\ldots]$ anet y miel de la que se haya retirado la espuma y consérvalo en un recipiente de vidrio [...].

${ }^{19}$ La palabra aparece en el margen. 
אש ושים אותה סמוך , לנקב. ויחמם מה שבתוכו. ויוציאן כל מה שבתוכוכוכו.

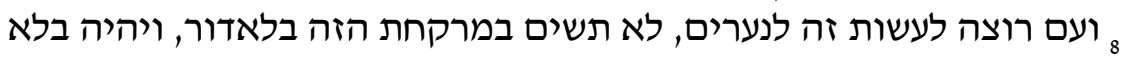

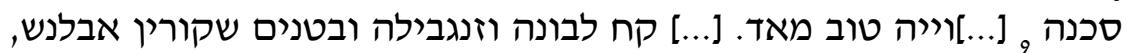

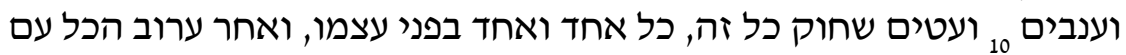

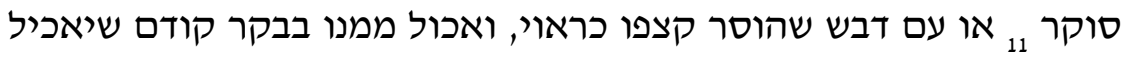
וזה טוב 12 מאד [....

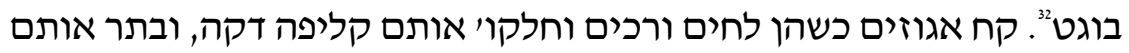

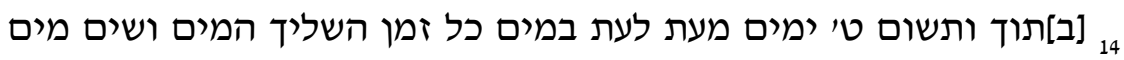
זכים ${ }_{15}{ }_{15}$ הסמים, 16 ואז טוב מאד. ואחי כום

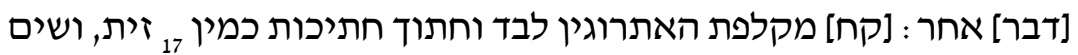

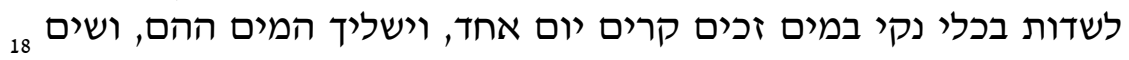

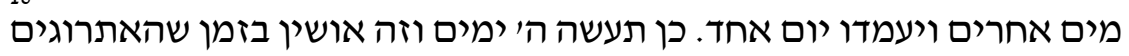
${ }_{19}{ }_{19}$

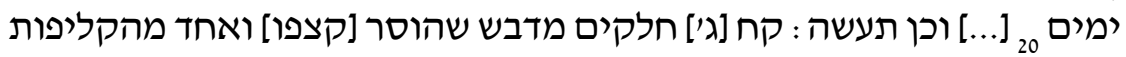

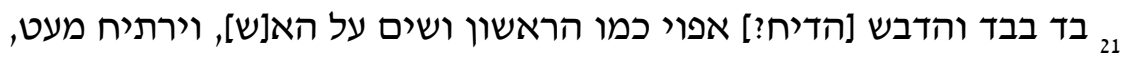

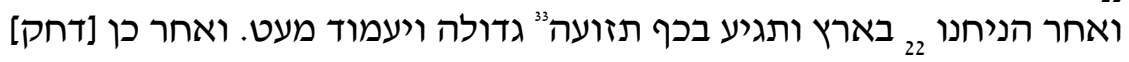

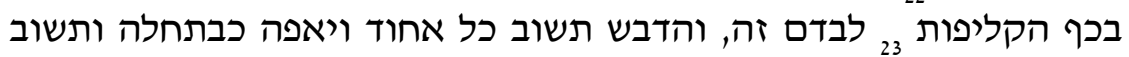
הקלפות בדבש ותש]י[ם 24 בו הסמנים הטובים ותצנים תשניעהות.

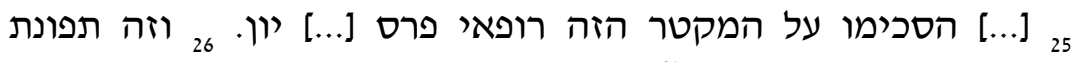

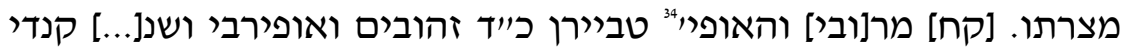

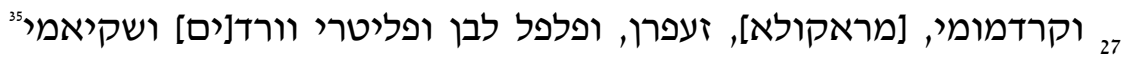

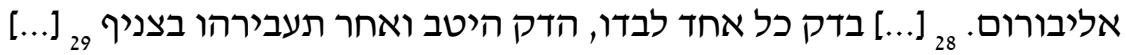

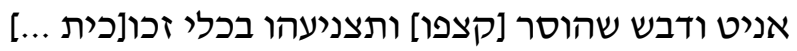

$$
\begin{aligned}
& 31 \\
& 32 \\
& 33 \\
& 34 \\
& 35 \text { שקמה }
\end{aligned}
$$




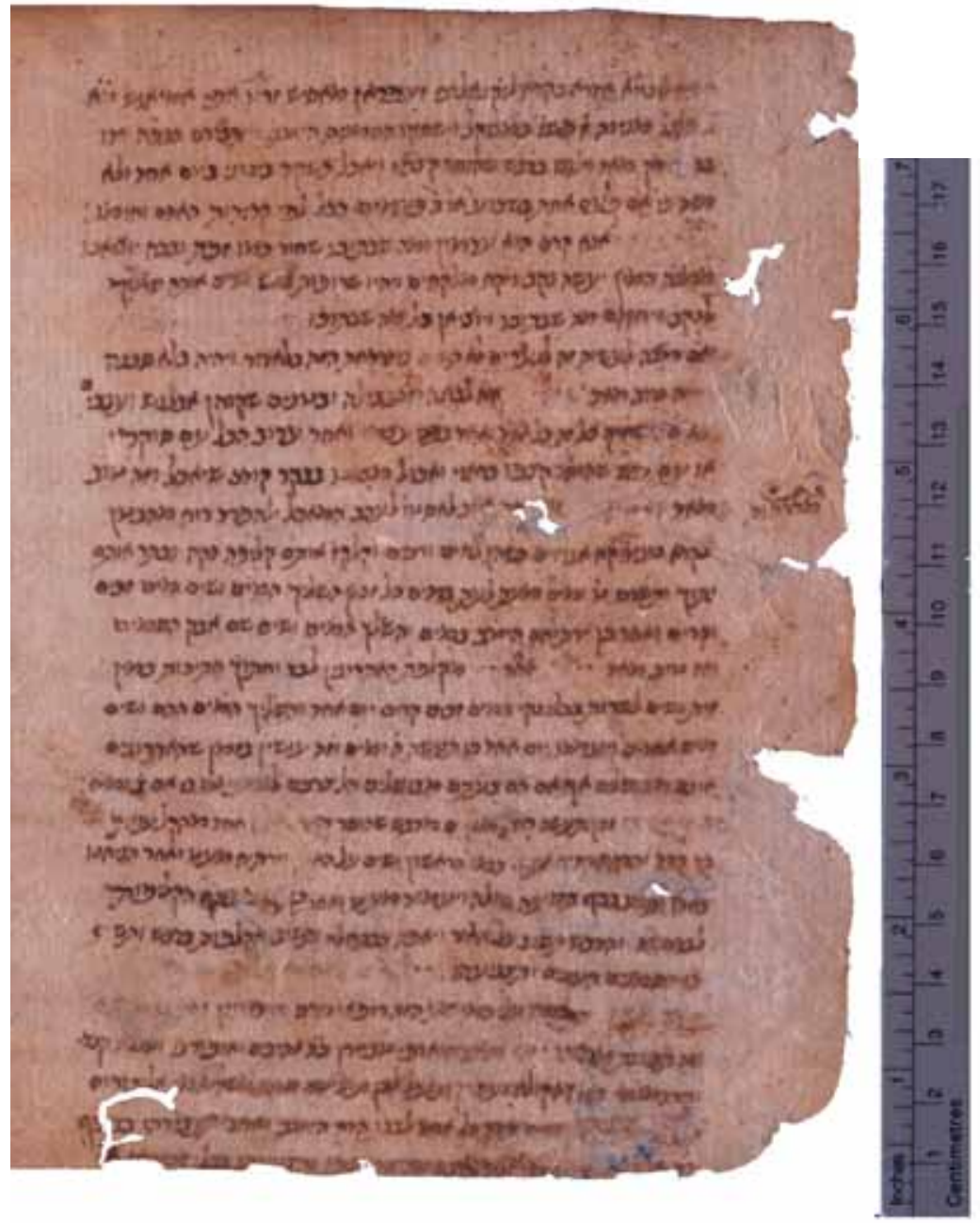

Figura 9. ( AMGi, Col·lecció de documents hebreus, HB23b v.

SEFARAD, vol. 74:1, enero-junio 2014, págs. 33-74. ISSN: 0037-0894. doi: 10.3989/sefarad.014.002 


\section{REFERENCIAS BIBLIOGRÁFICAS DEL GLOSARIO}

Reuven Alcalay, The Complete Hebrew-English Dictionary (Tel-Aviv-Jerusalem, 1965).

Miguel Asín Palacios, Glosario de Voces Romances: registradas por un botánico anónimo hispanomusulmán (siglos XI-XII) (Madrid-Granada: CSIC, 1943) [= Asín].

Ron BARKaI, A History of Jewish Gynaecological Texts in the Middle Ages (Leiden/Boston: Brill, 1998) [= Barkai].

Carmen Caballero Navas, El Libro de Amor de Mujeres (Granada: Universidad, 2003).

Joan Corominas, Diccionari etimològic $i$ complementari de la llengua catalana (Barcelona, 1980) [= DECLC].

Joan Corominas y José A. Pascual, Diccionario Crítico etimológico Castellano e Hispánico (Madrid, 1983) [= DCECH].

Lola Ferre, Práctica de Johannes de Parma. Un tratado farmacológico en sus versiones hebrea y catalana (Granada: Universidad de Granada, 2002) $[=\mathbf{P J P}]$.

Pio Font Quer, Plantas Medicinales: El Dioscórides renovado (Barcelona: Editorial Labor, 1962) [= Font $]$.

Monica H. Green, The Trotula. An English Translation of the Medieval Compendium of Women's Medicine (Philadelphia: University of Pennsylvania Press, 2001/2002) [= Trotula].

Walther HINz, Islamische Masse und Gewichte, umgerechnet ins Metrische System (Leiden-Köln: E. J. Brill, 1970²) [= Hinz].

Jacob LevY, Wörterbuch über die Talmudim und Midraschim (Darmstadt, $\left.1963^{2}\right), 4$ vols.

Adamus Lonicerus, Kreuterbuch (Frankfurt, 1679; reimpr. München, 1962) [= Lon].

SEFARAD, vol. 74:1, enero-junio 2014, págs. 33-74. ISSN: 0037-0894. doi: 10.3989/sefarad.014.002 
José Ramón Magdalena Nom De Deu, Un glosario hebraicoaljamiado trilingüe y doce «aqrabadin» de origen catalán (siglo xv). Edición paleográfica, introducción y notas (Barcelona: Universidad de Barcelona, 1994) [= Magdalena].

Ma Adélia Soares de Carvalho Mendes, Pedro Hispano. Tesoro de los Proves. Versão em Judeu-Castelhano Aljamiado (séc. XV) [= Mediaevalia 15-16] (1999).

Wilhelm PAPE, Griechisch-Deutsches Handwörterbuch (Graz: Akademische Druck- u. Verlagsanstalt, 1954³).

Ma Concepción Vázquez de Benito y Camilo Alvarez Morales, El libro de las Generalidades de la Medicina [Kitab al-Kulliyyat fil-țibb] de Abū-lWalìd Ibn Rušd (Averroes) (Madrid: Trotta, 2003) [= Gen].

Hans WeHR, Arabisches Wörterbuch für die Schriftsprache der Gegenwart (Wiesbaden: Harrasowitz, 1958) [= Wehr].

Diccionari de la llengua catalana (Barcelona: Institut d'Estudis Catalans, 2011²) [= DLCIEC $]$.

Diccionario de la Lengua Española, Real Academia Española, (Madrid: Espasa Calpe, 1992 ${ }^{21}$ ) [= DLERAE]. 


\section{GLOSARIO}

TÉRMINOS BOTÁNICOS Y ANIMALES

\begin{tabular}{|c|c|c|}
\hline אבלנש & 'ablnš & $\begin{array}{l}{[23 \mathrm{~b} \text { v/9] avellanas (< lat.; abellana, s. }} \\
\text { XIII); DCECH s.v. }\end{array}$ \\
\hline אברות - - - - - - & 'abrūt & [23a r/4] abrojo (cat. abrull); Font 422 \\
\hline 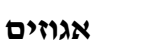 & 'egōzīm & [23b v/13] nueces (hebr.) \\
\hline 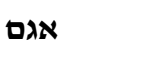 & 'agm & [27a r/5] junco, caña (hebr. אגמון) \\
\hline 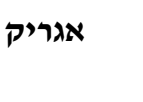 & 'agarīc & 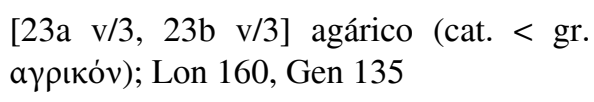 \\
\hline 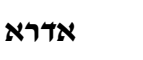 & 'edra & [23b v/1] arce, cedro (hebr.) \\
\hline 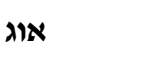 & 'ōg & [27a v/5] zumaque (hebr.) \\
\hline 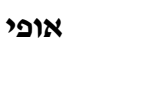 & 'ōpì & $\begin{array}{l}{[23 \mathrm{~b} \text { v/26; 27a r/24; 27b v/17] opio; (cat. }} \\
\text { opi); DLCIEC s.v. }\end{array}$ \\
\hline 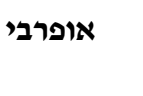 & 'ōfirbī & $\begin{array}{l}{[23 \mathrm{~b} \text { v/26] euforbio (< lat. euphorbia); }} \\
\text { Lon } 564 \text { y 736; DCECH s.v. }\end{array}$ \\
\hline 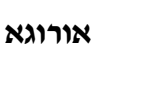 & 'ōrūga & $\begin{array}{l}{[23 \mathrm{a} \text { v/25] oruga }(<\text { lat. eruca sativa); Font }} \\
267 ; \text { Lon } 371 \mathrm{ss}\end{array}$ \\
\hline 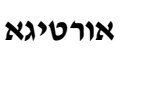 & 'ōrțīga & $\begin{array}{l}{[23 \mathrm{a} v / 23,28 ; 27 \mathrm{a} r / 3,9] \text { ortiga }(<\text { lat. ur- }} \\
\text { tica); Font } 132 \text {, Lon } 255 \text {, Gen } 295\end{array}$ \\
\hline אוריגאני & 'ōrēganē & $\begin{array}{l}\text { [27a r/2] orégano (< lat. origanum); Font } \\
695 ; \text { Lon } 274 \mathrm{ss}\end{array}$ \\
\hline 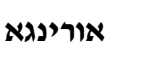 & 'ōrēnga & [23a v/28] orégano (cat. orenga); Font 695 \\
\hline 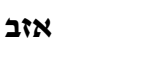 & 'ezob & [27a v/6] hisopo (cat. hisop) (hebr.) \\
\hline איליאון & '̄̄lēōn & $\begin{array}{l}{[23 \mathrm{~b} \text { r } / 19,20] \text { enfermedad del colon }(<\mathrm{gr} .} \\
\varepsilon \dot{\lambda}(\lambda \mathrm{s}), \text { DCECH s.v. íleo }\end{array}$ \\
\hline איריאוש & '̄îēè ōš & $\begin{array}{l}{[27 \mathrm{a} \text { v/10] lirio (lat. vulgar < lat. iris flo- }} \\
\text { rentina), Lon } 916\end{array}$ \\
\hline 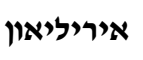 & 'īrēlè'ōn & {$[27 \mathrm{a}$ v/6, 8] aceite de iris, Trotula 147} \\
\hline אירינגי & 'èrīngē & $\begin{array}{l}{[27 \text { a r/4, 12] cardo corredor (< lat. eryn- }} \\
\text { gium); (cat. card panical); Font } 478, \text { Lon } \\
192\end{array}$ \\
\hline
\end{tabular}


64

אישנץ /אשינץ

\begin{tabular}{|c|c|}
\hline אלה & 'elā \\
\hline אלום & 'alūm \\
\hline אליבורום & 'elēbōrūm \\
\hline אמיאוש & 'amē'ōš \\
\hline אנאקרדי & 'anācardī \\
\hline אנגילי & 'anagīlī \\
\hline אניש /-ס/-ז & 'anīšs/-s/ -z \\
\hline ייט & 'anēṭ \\
\hline
\end{tabular}

אפי

אפראסא

ארגון

ארונידקו

ארי

ארנבת

ארשמישא

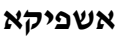

[23b r/ 9, 13] ajenuz (< hispanoárabe šanûz; lat. nigella sativa); (cat. pebreta); Gen 319, Font 212, DCECH s.v. ajenuz [23b r/23] terebinto (hebr.)

[27a v/6; 27b v/18] alumbre (< lat. alum gallicum); Lon 712, DCECH s.v. alumbre [23b v/27] eléboro (< lat. helleborus, < gr. $\varepsilon \lambda \lambda \dot{\varepsilon} \beta о \rho \circ \varsigma) ;$ Lon 385, DCECH s.v.

[23b v/1] ameos (< gr. $a \mu \mu \mathrm{i})$; Lon 480, DCECH s.v.

[23a r/26; 23b v/5] anacardo (cat. anacard < lat. anacardum); Lon 153, DCECH s.v.

[23a v/5] cárdeno (cat. anagall < lat. anagallis); Lon 377, Font 523, Asín 138

[23a r/24; 23a v/15 y 23; 23b r/2; 27a v/10] anís

[23b r/25; 23b v/29] eneldo (cat. anet < lat. anethum); Font 500, DCECH s.v. eneldo

[23a v/1 y 25; 23b r/2] apio (< lat. apium graveolans); (cat. api); Font 487

[23a r/3] ácoro; Lon 536

[23a v/2] un tipo de ungüento; Trotula 87

[23a v/10] barba de Arón (diminutivo) (< gr. ápov); Lon 427, Font 960

[27a r/3] zarzaparilla; (cat. Ari[jol]); Font $907 \mathrm{ss}$

[27a v/16] liebre, conejo (hebr.)

[23a r/17] artemisa (< lat. artemisia vulgaris); Font 815, DCECH s.v.

[23a r/24 y 23a v/10, 15] lavanda, espliego; (cat. espic); Font 654 


\begin{tabular}{|c|c|c|}
\hline 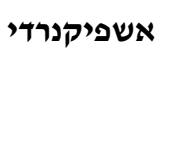 & 'ešpīcnardī & $\begin{array}{l}\text { [23a v/10, 11] espicanardo (cat. espica- } \\
\text { nard < lat. spica nardi); Lon 284, DCECH } \\
\text { s.v. espiga }\end{array}$ \\
\hline אשפרגי & 'ašpargui & 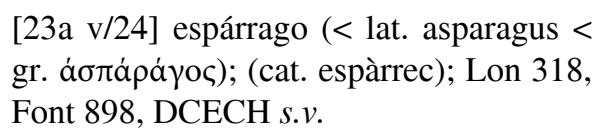 \\
\hline 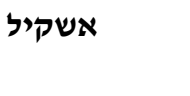 & 'ešquīl & $\begin{array}{l}\text { [23a r/25] escila, cebolla albarrana }(<\text { ar. } \\
\text { إسققيل); (cat. escil.la); Font 895, Wehr }\end{array}$ \\
\hline אשקיננט & 'ešquīnanț & $\begin{array}{l}\text { [23a v/15] esquinanto; (cat. esquinant }< \\
\text { lat.); Lon } 539 \text { s.v. schoenantum, DECLC } \\
\text { s.v. }\end{array}$ \\
\hline אשקמוניאה & 'ešcamōn̄̄'à & $\begin{array}{l}{[27 \mathrm{a} v / 2] \text { escamonea }(<\text { gr. } \sigma \chi \alpha \mu \mu \omega v i \alpha)} \\
\text { DCECH s.v. escamar, PJP } 131\end{array}$ \\
\hline אשקמת & 'asiqmat & [27a v/2] sicómoro (hebr.) \\
\hline אתרוגין & 'etrōgīn & [23b v/16 y 18] cidras (hebr.) \\
\hline 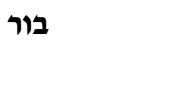 & bōr & $\begin{array}{l}\text { [23b r/11] borraja (< lat. borago officina- } \\
\text { lis L.); DCECH s.v. }\end{array}$ \\
\hline בורטולייגא & bōrțōlaīga & $\begin{array}{l}{[23 \mathrm{~b} \mathrm{r} / 21 \text { y } 22 ; 27 \mathrm{a} r / 22] \text { verdolaga }(<\text { lat. }} \\
\text { portulaca); (oc. bortolaiga); Lon } 171 \text {, Font } \\
165\end{array}$ \\
\hline בטנה /בטנים & boṭne/boṭnīm & $\begin{array}{l}\text { [23a v/21 avellanas; } 23 \mathrm{~b} \text { v/9] pistachos, } \\
\text { piñones (hebr.) }\end{array}$ \\
\hline 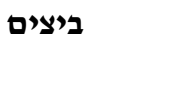 & bēṣìm & $\begin{array}{l}\text { [27a r/22; 27b v/ } 7 \text { y 9] testículos, huevos } \\
\text { (hebr.) }\end{array}$ \\
\hline בלאדור & bal'ādōr & $\begin{array}{l}\text { [23 a r/20 y 26; 23b v/8] anacardo (hebr. } \\
\text { בלדְור); Magdalena } 7\end{array}$ \\
\hline בלידא & blēda & [27a r/15] acelga; (cat. bleda); Font 150 \\
\hline 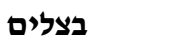 & beșalīm & [23qa v/28] cebollas (hebr.) \\
\hline ברושא & berōša & [27b v/15 y 17] ciprés, eneldo (hebr.) \\
\hline גטלא & gațela & $\begin{array}{l}\text { [27b v/18] sauce; (cat. gatell); Lon } 77 \text {, } \\
\text { DECLC s.v. gatell }\end{array}$ \\
\hline גירופלי & gīrōflē & $\begin{array}{l}\text { [27a r/3 y } 8 \text { ] giroflé, clavo de especia }(< \\
\text { lat. caryophyllon); PJP 134, DCECH s.v. } \\
\text { cario }\end{array}$ \\
\hline
\end{tabular}


גילסמני

גלבסי

גלנגא

גנסיאנה

גרוג

גרנגל

דבש

דגים חדשים

דונג

דפני לאון

דרגגן

הדס

וורד

ויאולא

זנגיבילה

זעפרא /זעפראן

זפת

זרעונים

חאלבי

חלב בקר

חלב חמורה z'afr'a(n)

gēlseman̄i

galabasī

galanga

gensî̀'anā

grōg

garengal

debaš

dagīm ḥadašīm

dōnag

dafnē le'ōn

dragagan

hadas

vered

vī’ōla

zanğîīīla

zefet

zere 'ōnīm

ḥ'alb̄̄

halab baqar

halab ḥamorā [23b r/23] clemátida flámula; (cat. gelsemi); Font 228 s., DLCIEC s.v.

[27a r/9] semilla de calabaza (cat. carabassí); DLCIEC s.v.

[27a r/6 y 8] galanga; DCECH s.v.

[27a v/6] genciana (< lat. gentiana); Lon 298, Font 727, DCECH s.v.

[23b r/5] amarillo (cat.); DECLC s.v.

[23a r/24] galanga, brezo ( > ar. halanğ); Wehr, DCECH s.v. galanga

[23b v/3, 11, 20, 21; 27b v/5] miel (hebr.)

[27a r/15] pescados frescos (hebr.)

[27b v/12 y 16] cera de abeja (hebr.)

[23b r/25] aceite de laurel (< lat. daphne laureola); Font 391 s.v. lauréola

[23b r/21] dragontea; (cat. dragonera); Lon 169, Font 961

[23a v/17] mirto, arrayán (hebr.)

[23b v/27; 27a r/24; 27b v/4] rosa (hebr.)

[23b r/22] violeta; (cat. viola); Font 288, DECLC s.v.

[23 a r/24; 23b v/9; 27a r/2] jengibre, enebro (< ar. زنجبي); (cat. ginebre); Font 82, Wehr

[23a v/23; 23b v/1 y $27 ; 27 \mathrm{a} \mathrm{r} / 2 ; 27 \mathrm{~b}$ v/5] azafrán (cat. safrá < ar. زعران); Font 915; Wehr

[23b v/5] brea, alquitrán (hebr.)

[27b r/11] legumbres (hebr.)

[23b r/13] fenogreco (> hebr. חלבה)

[27b v/22] leche de vaca (hebr.)

[23b v/20] leche de burra (hebr.) 


\begin{tabular}{|c|c|c|}
\hline חלב כבש & ḥalab kebes & [23a r/8] leche de oveja (hebr.) \\
\hline חלב עז וצאן & ḥalab 'ez ve-șon & $\begin{array}{l}{[27 \mathrm{~b} \text { v/22] leche de cabra y de oveja }} \\
\text { (hebr.) }\end{array}$ \\
\hline חלב עזים & ḥalab 'izīm & [23b r/21] leche de cabras (hebr.) \\
\hline טרי & $\operatorname{tar} \overline{1}$ & טרי . \\
\hline כמון & kamōn & $\begin{array}{l}{[27 b \text { v/12] comino (hebr. < ar. كمون); }} \\
\text { Wehr }\end{array}$ \\
\hline 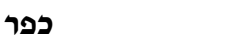 & kofer & [23b r/12] alheña (hebr.) \\
\hline כרישין & kerišīn & [27b v/20] puerros (hebr.) \\
\hline 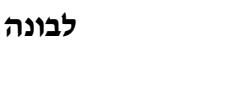 & lebonā & $\begin{array}{l}{[23 \mathrm{a} \text { r/14 y } 29 ; 23 \mathrm{~b} v / 9 ; 27 \mathrm{~b} \text { v/12] incien- }} \\
\text { so, resina (hebr.) }\end{array}$ \\
\hline לברין & labrīn & $\begin{array}{l}\text { [23a v/2] laurel (< lat. laurus nobilis); Lon } \\
70 \text { Barkai } 181\end{array}$ \\
\hline 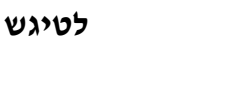 & lețigeš & $\begin{array}{l}{[23 \text { a v/11] lentejas de agua ( }<\text { lat. lentigo); }} \\
\text { Lon } 390\end{array}$ \\
\hline ליקנ’ אלובי & līqn(um) 'aloue & $\begin{array}{l}{[23 \mathrm{~b} \text { v/1] madera de aloe, linaloe }(<\text { lat. }} \\
\text { lignum aloe); Lon } 543\end{array}$ \\
\hline לשקודינש & leškōdīnš & [23b r/4] (voz no identificada) \\
\hline משטיג /מאסאיג & masțīg/ māsțīg & 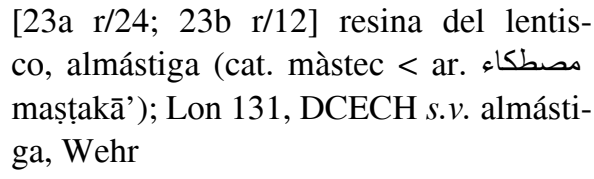 \\
\hline 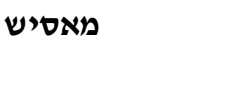 & māsīš & $\begin{array}{l}\text { [23b v/1] cáscara de la nuez moscada, ari- } \\
\text { lo; (cat macís); DCECH s.v. macís }\end{array}$ \\
\hline מיץ & mīṣ & jugo, zumo (hebr.) \\
\hline 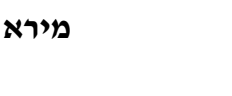 & mīra & $\begin{array}{l}{[27 \mathrm{a} v / 6 ; 27 \mathrm{~b} \text { v/12] mirra }(<\mathrm{ar} . \text { رurr }) \text {; }} \\
\text { Lon 738, DCECH s.v., Wehr }\end{array}$ \\
\hline מלבה /מלבא & malbā/malb’a & [23b r/21; 27b v/7] malva; Font 404 \\
\hline מלילוד /-ת & melīlōd/ -t & $\begin{array}{l}{[27 \mathrm{a} \text { v/10; } 27 \mathrm{~b} \text { v/4 y 9] meliloto }(<\mathrm{gr} \text {. }} \\
\left.\mu \varepsilon \lambda_{ } \lambda \omega \tau \mathrm{T}\right) \text { ); (cat. melilot); Lon } 250 \text { ss., } \\
\text { Font } 368\end{array}$ \\
\hline מנטא /-ה & mența & [23b v/2; 27a r/2 y 9] menta; Font 704 \\
\hline
\end{tabular}




\begin{tabular}{|c|c|c|}
\hline מרטה /מראטה & murța/ murața & $\begin{array}{l}\text { [23b r/26; 27a r/9; 27a v/2] mirto, arrayán } \\
\text { (< gr.), (cat. murta); Lon 139, Font } 396\end{array}$ \\
\hline 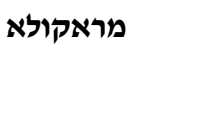 & mar'ācōla & $\begin{array}{l}\text { [23b v/27] azucena silvestre, martagón }(< \\
\text { lat. lilium martagon); (cat. marcori, mar- } \\
\text { còlic); Font } 892\end{array}$ \\
\hline מרובי לבן & marūbī laban & $\begin{array}{l}\text { [23a r/1 y 7) marrubio blanco (cat./hebr.); } \\
\text { Lon } 259 \text {, Font } 659 \text {, DCELC s.v. malrubí }\end{array}$ \\
\hline 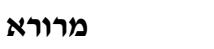 & merōra & [27b v/1] cerraja (hierbas amargas) (hebr.) \\
\hline 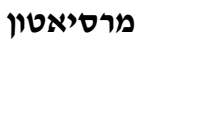 & marsî’ațōn & $\begin{array}{l}\text { [23a v/2] (voz no identificada); podría tra- } \\
\text { tarse de ("salvado') y טרסן ("jugo, jugo } \\
\text { de salvado); Levy s.v. }\end{array}$ \\
\hline נאפש /נאבש & naps/ nabs & $\begin{array}{l}\text { [23a v/18; 27a r/4] nabos (cat.); DECLC } \\
\text { s.v. naps }\end{array}$ \\
\hline נשיטורט & nešīṭōrṭ & $\begin{array}{l}\text { [23a v/23] mastuerzo, berro (< lat. nastur- } \\
\text { tium officinale); Lon } 507 \text {, Font } 273 / 4\end{array}$ \\
\hline 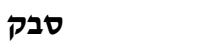 & sabuc & [27a r/6] saúco; (cat. saúc); DECLC s.v. \\
\hline סבוקו /ספקו & sabūcō/safcō & $\begin{array}{l}{[27 \text { a r/5 y } 7 ; 27 \text { a v/7] saúco (< lat. sambu- }} \\
\text { cus); Font } 752\end{array}$ \\
\hline סומך - - - & sūmak & $\begin{array}{l}\text { [27b v/17] zumaque (cat. sumac < ar. سماق } \\
\text { summāq); Lon 133, Font 444, Wehr }\end{array}$ \\
\hline 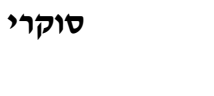 & sūcrē & $\begin{array}{l}\text { [23b v/10] azúcar (cat. < ar. سكر- sukkar); } \\
\text { Wehr, DECLC s.v. sucre }\end{array}$ \\
\hline 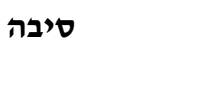 & sēbā & $\begin{array}{l}\text { [23a v/20] cebolla, (cat.); DECLC s.v. } \\
\text { ceba }\end{array}$ \\
\hline סינאמומו & sīnamōmō & 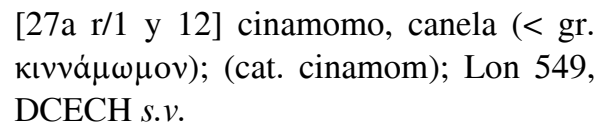 \\
\hline 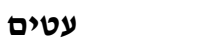 & 'ațayīm & [23b v/10] arilos (hebr.) \\
\hline עלי & 'elī & [23a v/1] pistilo (hebr.) \\
\hline ענב /ענבים & 'enab/ 'anabīm & [23a v/17; 23b v/9] uva/ uvas (hebr.) \\
\hline עפרסיא & 'efrasī’a & 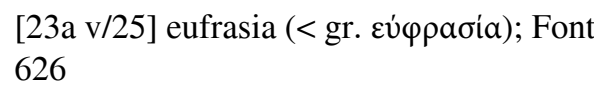 \\
\hline ערמון & 'armōn & [23b v/5] castaña (hebr.) \\
\hline
\end{tabular}




\begin{tabular}{|c|c|c|}
\hline 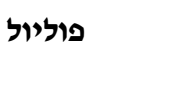 & pōlīōl & $\begin{array}{l}\text { [23b r/2] tomillo (cat.); Font } 650, \text { DECLC } \\
\text { s.v. poliol }\end{array}$ \\
\hline 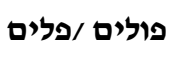 & pōlīm/ plīm & [23a v/18 y 19; 27b v/6 y 9] judías (hebr.) \\
\hline פורש & pōroš & $\begin{array}{l}{[27 \mathrm{~b} \text { v/20] puerros (cat. porros); DECLC }} \\
\text { s.v. }\end{array}$ \\
\hline 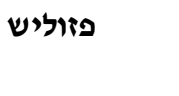 & fezōlēš & $\begin{array}{l}\text { [23a v/11] frijol, judía (cat. fesoles < lat. } \\
\text { faseōlus); DECLC s.v. fesol }\end{array}$ \\
\hline 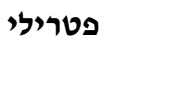 & pețrīlī & $\begin{array}{l}{[23 \mathrm{a} \text { v/12] perejil }(<\text { lat. petroselinum hor- }} \\
\text { tense); Font } 490\end{array}$ \\
\hline פיליטרי & pēlītrēè & $\begin{array}{l}\text { [23b v/27; 27a r/4] pelitre (< lat. pyreth- } \\
\text { rum); Lon } 485 \text {, Font } 812\end{array}$ \\
\hline פליטונש & plēṭōnš & $\begin{array}{l}\text { [23a v/9] bálsamo/ agua de rosas (hebr. } \\
\text { con desinencia cat. -s) }\end{array}$ \\
\hline 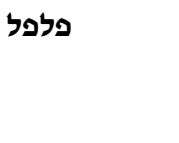 & pilpel & $\begin{array}{l}{[27 \text { a r/3 y 12; 23a v/28] פלפל ארוך ('pi- פלפל לבן ["pi- }} \\
\text { miento largo'); [23b v/27- } \\
\text { miento blanco') (hebr.) }\end{array}$ \\
\hline 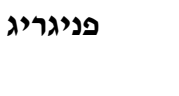 & fenīgrēg & $\begin{array}{l}\text { [23a r/19] fenogreco (< lat. trigonella foe- } \\
\text { num-graecum); (cat. fenogrec); Font } 366\end{array}$ \\
\hline 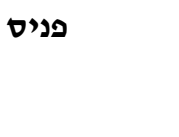 & panīs & $\begin{array}{l}\text { [23b r/28; 23a v/1;27a r/5 y 6] panizo }(< \\
\text { lat tardío panicium); (cat. panis); Lon } 526 \text {, } \\
\text { DECLC s.v. }\end{array}$ \\
\hline פשתן & pištan & [23a v/23; 23b r/6; 27a r/6] lino (hebr.) \\
\hline 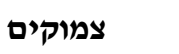 & șimūquīm & [27b v/9] uvas pasas (hebr.) \\
\hline קבקילש & cauquīles & $\begin{array}{l}\text { [23a v/7] conchas (fr. cauquilles, cat. con- } \\
\text { quilles); Lon } 702\end{array}$ \\
\hline קבריא & cobrē' & [23a r/9] cobre; cat. coure; DCECH s.v. \\
\hline קוקורביתא & cōcōrbīta & $\begin{array}{l}\text { [23b r/22; 27a r/15 y 16] calabaza (lat.); } \\
\text { cat. (carbasso); Lon } 442\end{array}$ \\
\hline קושט & cošț & $\begin{array}{l}\text { [23a v/23] salvia romana, balsamita (cat. } \\
\text { cost); Lon 541, Font } 814\end{array}$ \\
\hline קיבת ארנבת & quebat 'arnebet & $\begin{array}{l}\text { [31b } 2 v / 3] \text { cuajo, estómago de conejo } \\
\text { (hebr.) }\end{array}$ \\
\hline
\end{tabular}


קלימנט

qlipat/ qlipot

קמומילא

קמח חטים

קמח שיעור

קמפורא

קנילה /קנילא

קרדמומי

קרינה

קריסות

קשיא

ראסין

רואה

רוביא

רדא /רודא

רומנינו

רמונים

רקליציא calēment

camōmīla

quemaḥ hịṭim

quemaḥ sē'ōr

camfōra

canēlā

cardamōmī

querīnā

querīsūt

cašì’a

rāsīn

rō'è

rūbī’a

rda/ rūda

rōmanīnō

rimōnīm

recalēṣī'a [23a v/13; 27a r/2; 27a v/1 y 7 y $10 ; 27$ b

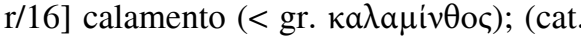
calament); Lon 262, Font 691

[23a v/23; 27b r/2] corteza(s) de, cáscara(s) de; (hebr.)

[23b r/25 y $26 ; 27 \mathrm{~b}$ v/5 y 11] manzanilla, (cat. camamilla); Font 809

[27b v/10] harina de trigo (hebr.)

[23a r/17; 27b v/5] harina de cebada (hebr. (שעורה)

[27a r/24; 27b v/17] alcanfor (cat. càmfora); Lon 735, Font 199

[23a r/24, 27a r/1] canela; DCECH s.v.

[23b v/27; 27a r/4 y 12] cardamomo; DCECH s.v.

[27a r/3] quillas de las leguminosas (hebr.)

[23a v/20] lo agrio (hebr.)

[23b v/1;27a r/2 y 13; 27a v/3 y 10] casia (< lat. cassia spec.); Lon 550

[27b v/19] reseda (< lat. sedum); (cat. rasin); Lon 171 s. DECLC s.v.

[27a r/15] excremento (hebr.)

[23b r/2; 27b r/4] rubia, ruibarbo (< lat. rubea tinctorum); Lon 499, Font 750

[23a r/6] ruda (< lat. ruta graveolans); Font 426 ss.

[23b r/2] romero (< lat. rosmarinus officinalis); (cat. romaní); Font 654, DCELC s.v. romero I

[27b r/2; 27b v/4] granadas (hebr.)

[23a v/12; 23b r/23] regaliz; (cat. regalessia); Font 376, DECLC s.v. 


\begin{tabular}{|c|c|c|}
\hline שבינה & sabīnā & $\begin{array}{l}{[27 \mathrm{a} v / 3 \text { ] sabina }(<\text { lat. juniperus sabina); }} \\
\text { Lon } 73 \text {, Font } 86\end{array}$ \\
\hline שגל & segel & $\begin{array}{l}\text { [27b r/9] sello de Salomón (< lat. vulg. } \\
\text { Sigillum salomonis); (cat. segell de Sa- } \\
\text { lomó); Lon. } 382 \text {, Font } 901\end{array}$ \\
\hline שולטרי & solțrē & $\begin{array}{l}\text { [27a r/22; 27b v/ 5, 8] belladona, solano } \\
\text { (< lat. solanum); it. solatro; Lon 198, Font } \\
563 \mathrm{ss}\end{array}$ \\
\hline שומן חזיר & šuman ḥazir & [27 b v/20] grasa de cerdo (hebr.) \\
\hline שומן כליות צבי & $\begin{array}{l}\text { šuman kelayot } \\
\text { șebī }\end{array}$ & $\begin{array}{l}\text { [27b v/12] grasa de los riñones del ciervo } \\
\text { (hebr.) }\end{array}$ \\
\hline שומן תרנגלת אליב & $\begin{array}{l}\text { šuman tarnegolet } \\
\text { 'alēb }\end{array}$ & [23b r/10] grasa de gallina blanca (hebr.) \\
\hline שומר & šumar & [23a v/12; 23b r/2] hinojo (hebr.) \\
\hline שילי & sìlī & $\begin{array}{l}\text { [23b r/22] algarroba; (cat. sil-li); Lon 132, } \\
\text { DECLC s.v. }\end{array}$ \\
\hline שילנקא & sīlanca & $\begin{array}{l}{[27 \mathrm{a} r / 15] \text { acelga }(<\text { ar. silka?); DCECH }} \\
\text { s.v. acelga }\end{array}$ \\
\hline שמבוק & sambūc & $\begin{array}{l}\text { [27a v/10] sauco (< lat. sambucus); (cat. } \\
\text { saúc); Font } 752\end{array}$ \\
\hline שמן גילסמני & šemen gēlsemanī & $\begin{array}{l}\text { [23b r/23] aceite de clemátide flámula } \\
\text { (hebr./cat. gelsemi);(< lat. gelsemium } \\
\text { sempervirens); Font } 228 \mathrm{ss} \text {, DLCIEC s.v. }\end{array}$ \\
\hline שמן וורד /-ים & $\begin{array}{l}\text { šemen vered } \\
(\text {-adīm })\end{array}$ & [27b v/8 y 15] aceite de rosas (hebr.) \\
\hline שמן ויאולד & šemen vī’ōlad & $\begin{array}{l}\text { [23b r/23] aceite de violetas (hebr./cat. vi- } \\
\text { olat) }\end{array}$ \\
\hline שמן זית & šemen zayit & $\begin{array}{l}{[23 \mathrm{~b} v / 17 ; 27 \mathrm{~b} \text { v/20] aceite de oliva }} \\
\text { (hebr.) }\end{array}$ \\
\hline שמן לברין & šemen lavrīn & $\begin{array}{l}{[23 \mathrm{a} \text { v/2] aceite de laurel (hebr./cat. < lat. }} \\
\text { oleum laurinum); lon } 70, \text { Barkai } 181\end{array}$ \\
\hline שמן קאממילא & šemen cāmomīla & $\begin{array}{l}\text { [23a v/14] aceite de manzanilla (hebr./ } \\
\text { cat.) }\end{array}$ \\
\hline שמן שקד & šemen šaqued & [23b r/24] aceite de almendra (hebr.) \\
\hline
\end{tabular}




\begin{tabular}{|c|c|c|}
\hline שמפר ויאה & semper vī’a & $\begin{array}{l}\text { [27a r/23] siempreviva (< lat.) (cat. sem- } \\
\text { perviva); Lon } 171 \text {, DLCIEC s.v. }\end{array}$ \\
\hline שעוה & ša'avā & [23b r/11; 27b v/22] cera (hebr.) \\
\hline שקדים & šeqadīm & [23b r/27; 27a r/4] almendras (hebr.) \\
\hline שקיאמי & šiquī'āmī & $\begin{array}{l}\text { [23b v/27] sicómoro (hebr. שקמה); Lon } \\
134\end{array}$ \\
\hline שרקא קולא & šarca cōla & $\begin{array}{l}\text { [23b r/12; 27b r/1 סרקא קולא] sarcocola } \\
\text { (< lat. sarcocolla), goma casi transparen- } \\
\text { te que fluye por la corteza de un arbusto } \\
\text { de Arabia parecido al espino negro); Gen } \\
\text { 740, DLERAE s.v. }\end{array}$ \\
\hline שתייתו & šattītō & [27a r/8] harina de cebada con miel (hebr.) \\
\hline תאנים צמוקות & te'enīm șamūcōt & [23b v/2] higos secos (hebr.) \\
\hline תות & tūt & [27b r/11] mora (hebr.) \\
\hline תמרות - - - - - - & temarōt & [27a r/17] dátiles (hebr.) \\
\hline
\end{tabular}

TÉRMINOS MÉDICOS, PESOS Y MEDIDAS

\begin{tabular}{|c|c|c|}
\hline 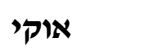 & 'oqīi(a) & [23a v/22 y $27 \mathrm{~b} v / 15]$ onza (hebr.) \\
\hline אפירמריא & 'afīrmerī’a & $\begin{array}{l}\text { [27b r/12] enfermería; (cat. infermería); } \\
\text { DECLC s.v. infermería }\end{array}$ \\
\hline אסטומאק & 'esțōmac & $\begin{array}{l}{[23 \mathrm{a} \text { r/21 y } 23 \mathrm{~b} \text { v/12] estómago; (cat. estó- }} \\
\mathrm{mac} \text { ); DECLC s.v. }\end{array}$ \\
\hline אשטובה & 'ešțūbā & $\begin{array}{l}\text { [27b r/8] baño de vapor; (cat. estuba); } \\
\text { DCECH s.v. estufa }\end{array}$ \\
\hline אשרוב & 'ešrōb & $\begin{array}{l}\text { [27a r/ 8] jarabe; (cat. xarop > ar. شربة); } \\
\text { DCECH s.v. jarabe; Wehr }\end{array}$ \\
\hline בגד דק & bēged dac & [23b v/3] tamiz (hebr.) \\
\hline בִִּיל & bōdēl & $\begin{array}{l}\text { [27b r/8] intestino (cat. budell < lat. botel- } \\
\text { lus); DECLC s.v. botiellu }\end{array}$ \\
\hline 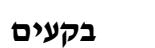 & beca'ìm & [27b v/19] hernias (hebr.) \\
\hline
\end{tabular}




\begin{tabular}{|c|c|c|}
\hline דרכמ' /דרכ' & dracma & $\begin{array}{l}\text { [27a r/3,4 ss.; 27a v/2,3;27b v/11,17] } \\
\text { dirhem, medida de peso equivalente a } \\
3,125 \text { gr (Hinz } 3)\end{array}$ \\
\hline להביא נדות & le-habī’ nidūt & $\begin{array}{l}\text { [27a v/16] para que venga la menstrución } \\
\text { (hebr.) }\end{array}$ \\
\hline 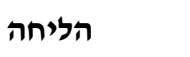 & ha-lēhā & [23a v/26 y 28] la flema, el humor (hebr.) \\
\hline הריון & herayōn & [23a r/3; 27a v/15 y 16] embarazo (hebr.) \\
\hline 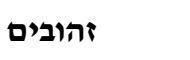 & zehūbīm & [23b v/26] monedas de oro (hebr.) \\
\hline ז & $\mathrm{zūz}$ & [23a v/3] moneda de plata (3,5 gr) (hebr.) \\
\hline 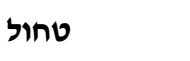 & țehọol & [23a v/10] bazo (hebr.) \\
\hline טס עופרת - - - & țas ‘ōfēret & [27b v/24] placa de plomo (hebr.) \\
\hline 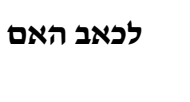 & le-ke'eb ha-'em & $\begin{array}{l}\text { [23b r/1 y 3] contra el dolor de la madre } \\
\text { (hebr.) }\end{array}$ \\
\hline 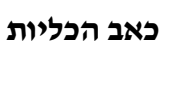 & ke'eb ha-kelayōt & $\begin{array}{l}\text { [23b r/18, 19, 26, y 28] dolor de riñones } \\
\text { (hebr.) }\end{array}$ \\
\hline כבד & kabēd & [23a v/10] hígado (hebr.) \\
\hline 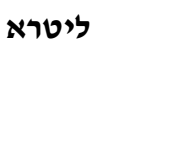 & lițra & $\begin{array}{l}\text { [24b v/2; 27a r/10;27b r/15] medida de } \\
\text { peso de líquidos equivalente a 358,21 gr } \\
\text { (hebr. < gr. } \lambda i \text { í } \rho \text { a) }\end{array}$ \\
\hline 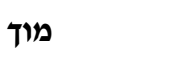 & mōk & [23a r/3 y 7; 27a v/5] pesario (hebr.) \\
\hline מי מרק & mē-maraq & [27b r/7] caldo (hebr.) \\
\hline מלגוירש & melgoires & $\begin{array}{l}\text { [23a } \mathrm{r} / 25] \text { (medida de peso) relativa a } \\
\text { Melgueil }\end{array}$ \\
\hline למנוע מהריון & limnō‘a me-heray & $\begin{array}{l}\text { ōn [27a v/14] para evitar un embarazo } \\
\text { (hebr.) }\end{array}$ \\
\hline מעי & me ${ }^{(-\overline{1}}$ & [23b r/28; 27b r/8] tripa, intestino (hebr.) \\
\hline מרקחת & mirqāḥat & $\begin{array}{l}\text { [23a r/20; } 23 \mathrm{a} \text { v/12 y } 26 ; 23 \mathrm{~b} \text { v/8] ungüen- } \\
\text { to (hebr.) }\end{array}$ \\
\hline 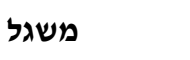 & mišgal & [23a v/16; 27a r/18, 20 y 24] coito (hebr.) \\
\hline 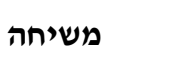 & mešīḥā & [23b r/9; 27b v/13 y 14] unción (hebr.) \\
\hline
\end{tabular}


משקל

נגעים

נדות

נפח הביצים

עקרה

פוגט

פורגישימוש

פרח

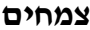

קלישטרי

רוב זקיפת אמה

רחמה

שיגדון

שקל

תחבושת

תשומת כלי mišqal

nega'ìm

nidūt

nēpaḥ ha-beșìm

'aqarā/-ot

fūgat

purgīsīmūs

pērah

șemahịim

clīsterī

[23a r/25; 23b v/2; 27a r/33] (hebr.) mitcal, medida de peso equivalente a 4,464 gr (Hinz 4)

[27a v/9] llagas (hebr.)

[27b r/12 y 13] menstruación (hebr.)

[27b v/20] hinchazón de los testiculos (hebr.)

[31b 2v/1] infértil /-es (hebr.)

[23b v/13] aire, ventosidad (cat.); DLCIEC s.v.

[27a r/19] gonorrea; DLERAE s.v. purgación

[27b r/13 y 16] «flor», eufemismo para menstruación (hebr.)

[27a v/9; 27b v/3] tumores (hebr.)

[23a v/13; 23b r/22] clister, lavativa; cat. crestiri; DECLC s.v.

rob zequifāt 'ammā[27a r/17] prolongada erección del pene (hebr.)

rehamā [23a r/11;31b/1] su útero (hebr.)

šigadōn [23a r/15] gota, reumatismo (hebr.)

šēquel [23a v/3] siclo, unidad de peso (hebr.)

tahbōšet

[27b r/4 y 6;27b v/13] venda, emplasto (hebr.)

tesōmet kelī [27a r/16] un recipiente apropiado (hebr.)

Recibido: 09/04/2013

Aceptado: $15 / 06 / 2014$ 